TI 2014-005/II

Tinbergen Institute Discussion Paper
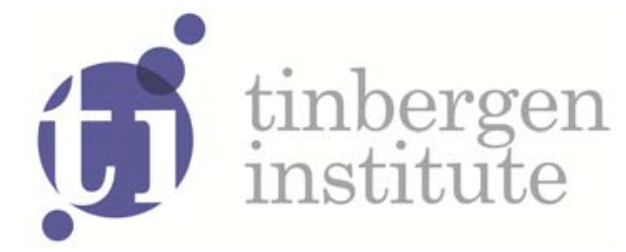

\title{
Assessing the Economic and Political Impacts of Climate Change on International River Basins using Surface Wetness in the Zambezi and Mekong Basins
}

Brian Blankespoor ${ }^{1}$

Alan Basist ${ }^{2}$

Ariel Dinar ${ }^{3}$

Shlomi Dinar4

Harold Houba ${ }^{5}$

Neil Thomas'

1 Development Research Group, World Bank, Washington DC, United States of America;

2 Weather Predict Consulting, Asheville, North Carolina, United States of America;

3 University of California, Riverside, California, United States of America;

4 Florida International University, Miami, Florida, United States of America;

5 Faculty of Economics and Business Administration, VU University Amsterdam, and Tinbergen Institute, The Netherlands;

${ }^{6}$ Resource Data Incorporated, Asheville, North Carolina, United States of America. 
Tinbergen Institute is the graduate school and research institute in economics of Erasmus University Rotterdam, the University of Amsterdam and VU University Amsterdam.

More TI discussion papers can be downloaded at http://www.tinbergen.nl

Tinbergen Institute has two locations:

Tinbergen Institute Amsterdam

Gustav Mahlerplein 117

1082 MS Amsterdam

The Netherlands

Tel.: +31(0)205251600

Tinbergen Institute Rotterdam

Burg. Oudlaan 50

3062 PA Rotterdam

The Netherlands

Tel.: +31(0)10 4088900

Fax: $+31(0) 104089031$

Duisenberg school of finance is a collaboration of the Dutch financial sector and universities, with the ambition to support innovative research and offer top quality academic education in core areas of finance.

DSF research papers can be downloaded at: http://www.dsf.nl/

Duisenberg school of finance

Gustav Mahlerplein 117

1082 MS Amsterdam

The Netherlands

Tel.: +31(0)20 5258579 


\title{
Assessing the Economic and Political Impacts of Climate Change on International River Basins using Surface Wetness in the Zambezi and Mekong Basins
}

\author{
Brian Blankespoor ${ }^{1}$, Alan Basist ${ }^{2}$, Ariel Dinar ${ }^{3}$, Shlomi Dinar ${ }^{4}$, Harold Houba ${ }^{5}$, Neil Thomas ${ }^{6}$ \\ ${ }^{1}$ Development Research Group, World Bank, Washington DC, USA \\ ${ }^{2}$ Weather Predict Consulting, Ashville, North Carolina, USA \\ ${ }^{3}$ University of California, Riverside, California, USA \\ ${ }^{4}$ Florida International University, Miami, Florida, USA \\ ${ }^{5}$ VU University Amsterdam, and Tinbergen Institute, Amsterdam, The Netherlands \\ ${ }^{6}$ Resource Data Incorporated, Asheville, North Carolina, USA
}

Many river basins will likely face higher hydrologic variability, including extreme floods and droughts, due to climate change, with economic and political consequences. Water treaties that govern international basins could face non-compliance among riparians and inter-state tensions as hydrologic variability increases. Accurate monitoring of water resources is essential to cope with these fluctuations in flow. This paper demonstrates a simple yet robust procedure - the Basist Wetness Index - to predict gauge station (actual water resources) measurements of surface wetness values derived from satellite data (for 1988-2013) and empirically derived flow distributions in two international river basins: Zambezi and Mekong. The paper further undertakes an economic analysis (applied to the Mekong), which identifies not only the economic costs and losses due to extreme flow events, but likewise showcases the benefits countries could potentially reap should they be able to make use of such flow data in real time. An illustrative application, using the wetness data and socio-political data, is also performed to highlight the utility of the procedure for research in the field of conflict and cooperation over water. The paper concludes that satellite data modeled with gauge station flow can help reduce the uncertainty inherent in negotiating international water issues. Moreover, the satellite observations can provide near real time monitoring of water resources, and provide valuable lead time for impending droughts and floods. Thus, the approach presented in the article can assist policy makers to devise more efficient and cooperative institutional apparatus.

Key words: runoff; remote sensing; surface wetness, hydrological variability; international relations; microwaves, economic optimization, international river basins; Mekong; Zambezi

JEL classification: C53, F51, F53, Q54 


\section{Assessing the Economic and Political Impacts of Climate Change on International River Basins using Surface Wetness in the Zambezi and Mekong Basins}

\section{INTRODUCTION}

Climatic conditions have a direct impact on the hydrology of a river basin. Climatic change will most likely affect the variability of river flows and have a variety of additional impacts on the hydrologic cycle (Jury and Vaux 2005; Miller and Yates 2006). The change in flow variability will affect populations that will no longer be able to plan water availability and supply trends (Milly et al. 2008). Changes will not be uniform and each region will experience either increases or decreases in river discharge compared with present observations (Palmer et al. 2008).

Hydrologic variability creates a significant challenge especially for countries sharing international river basins. Unanticipated high or low flow events may lead to flooding damage, severe drought, destruction of infrastructure, water resource conflicts and/or fatalities. These events can give rise to economic shocks and political tensions such as armed conflict (Drury and Olson 1998; Nel and Righarts 2008; Hendrix and Salehyan 2012). In the context of inter-state relations, political tensions or other types of water-related events may unfold even in basins where mitigating institutions (like water treaties) have been negotiated. In other words, climate change could increase the probability of flow below treaty specifications and expectations, leading to non-compliance and consequent political tensions between riparians.

Consequently, when designing water agreements or appending an outdated one, water negotiators need to forecast the distribution of water flow, in order to design the effective treaty. Having high quality flow data will also determine the appropriate treaty stipulations and institutional mechanisms that can deal with future challenges. Real time data can also provide policy makers and researchers with the ability to predict extreme weather events, and address their economic impact on an existing treaty or shared river basin.

Flow estimation models are already available to policy analysts. However, they require improvement to increase the accuracy of the results, and expand their utility. This paper contributes to the growing literature of methodologies to monitor and predict water resources, by introducing the Basist Wetness Index (BWI) to the context of international river basins. The methodology predicts natural runoff distributed across the basin by using sub-basin stream flow information and remotely sensed information to estimate the basin level run-off. The paper 
begins by contextualizing the discussion of the BWI in the recent literature on institutional capacity. It then delves into the mechanics of the Index with comparison to other methodologies and application to the Zambezi and Mekong. The paper then discusses the utility of the BWI for both economic and institutional analysis as well as research in conflict and cooperation over freshwater.

\section{The Socio-Political Context: Uncertainty, Security, And Institutional CAPACITY}

Although flow variability and related extreme events have already been observed across river basins, climate change is predicted to change flow rates and/or increase variability, as well as climate-driven natural disasters (Dai et al. 2009; Milly et al. 2008). One of the most forceful characterizations of the links between climate change and flow variability came out of a 2008 Technical Report of the Intergovernmental Panel on Climate Change, claiming that increased precipitation intensity and variability will increase flooding and drought in many areas, which will affect food stability, water quality, as well as exacerbate many forms of water pollution (Bates et al. 2008: 3-4). Such environmental changes could also aggravate political tensions, increasing the vulnerability of certain regions, and present substantial challenges to water infrastructure and services (Vörösmarty et al. 2000: 287; Kabat et al. 2002: vii; IPCC 2007: 49). Empirical studies have begun to investigate the utility of particular institutional mechanisms across a large number of treaty observations (Dinar et al. 2012; De Stefano et al., 2012).

Perhaps even more important than addressing changing flow under climate change is predicting the flow variability in near real time. In fact, treaty mechanisms and stipulations are most efficiently negotiated and devised when reliable data are available (McCaffrey 2003; Turton 2003; Drieschova, Giordano and Fischhendler 2008). In this manner, negotiators and policy makers are able to make educated decisions pertaining to which mechanisms and stipulations to include mitigating conflicts and effectively sharing water resources. Consequently, this would allow policy makers to anticipate possible shocks or extreme events and design appropriate solutions.

\section{EXISTing RUN-OfF ESTIMATION METHOdOLOGIES}


Applications of remote sensing to hydrology have improved dramatically over the past decade. Motivated by global risk analysis, approaches by Peduzzi et al. (2009) and Herold and Mouton (2011), for example, produced global maps of estimated flood areas derived from the link of the gauge observations to globally available remote sensing data, using Geographic Information Systems (GIS). In addition, existing methods that assess global climate change can also be used to estimate run-off, by calculating the percent change from a long-term normal. These predictions are then compared to the expected values provided by the Intergovernmental Panel on Climate Change (IPCC) General Circulation Model(s) (e.g. Palmer et al. 2008). All of these methods present operational challenges. First, global models tend to be complex and require many inputs that are not readily available; therefore they must be interpolated or derived from other variables. Second, global models are useful for global comparisons of basins; however policy work on specific treaties benefit greatly from basin specific analyses and applications. Third, the lack of timely (near real time) input data frequently limits updates, which in turns restricts many of these models from being used in a monitoring and mitigation capacity.

In contrast, the Basist Wetness Index (BWI) is based on globally consistent data that is available in near real time. The historical extent of the data (24 years) allows for an effective base period to calibrate regional relationships between the available water to local river discharge (Basist et al. 2001; Blankespoor et al. 2012). Moreover, the BWI integrates a multitude of factors: rainfall, snowmelt, evapotranspiration rates, soil infiltration rates, and irrigation into a single useful variable to predict river discharge. In addition, the real time availability of the data under almost all sky conditions allows one to continuously update the models for monitoring and mitigation activities across regions and national boundaries.

\section{Methodology fOR MOdeling SURfACE WeTNeSS WiTh FLOW}

\subsection{Surface wetness (BWI)}

Considering the challenges of global models, we demonstrate a simple yet robust procedure to predict gauge station flow measurements from surface wetness values derived from satellite data by basin. We utilize the BWI as a surface wetness index that ranges from zero, which represents no water detected near the surface, to a percentage of the radiating surface that is liquid water. Therefore the range goes from 0 to 100 , where 100 means the entire surface is liquid water (Basist et al. 1998). This index is derived from a linear relationship between channel 
measurements (Equation 1), where a channel measurement is the value observed at a particular frequency and polarization (i.e. the Special Sensor Microwave Imager-SSM/I observes seven channels).

$$
\text { [1] } B W I=\Delta \varepsilon \cdot T_{s}=\beta_{0}\left[T_{b}\left(v_{2}\right)-T_{b}\left(v_{1}\right)\right]+\beta_{1}\left[T_{b}\left(v_{3}\right)-T_{b}\left(v_{2}\right)\right] \text {, }
$$

where the change of emissivity (Basist et al. 2001), $\Delta \varepsilon$, is empirically determined from global $\mathrm{SSM} / \mathrm{I}$ measurements, $T_{s}$ is surface temperature over wet or dry land, $T_{b}$ is the satellite brightness temperature at a particular frequency $(\mathrm{GHz}), v_{n}(n=1,2,3)$ is a frequency observed by the $\mathrm{SSM} / \mathrm{I}$ instrument, $\beta_{0}$ and $\beta_{1}$ are estimated coefficients that correlate the relationship of the various channel measurements to observed surface temperature at the time of the satellite overpass. Specifically, the greater the wetness value is, the larger are the differences between the observed surface temperature and the observed channel measurements.

\subsection{Precipitation and BWI in relation to runoff}

Since both precipitation and BWI are important determinants of runoff, models of precipitation and BWI are calculated in order to compare the accuracy and level of significance of both types of predictor models. We hypothesize that the BWI model has a higher accuracy to predict flow observed from a gauging station than those based on a global precipitation model. The hypothesis is based on the realization that runoff is compounded by many factors, such as snowmelt, soil texture, irrigation, vegetation, solar isolation, relative humidity, and wind speed. All these factors are difficult to measure separately and they vary spatially from in situ observations. Moreover, the lack of reliable precipitation data can be a major constraint in many regions of the world. Given that the satellite captures the spatial structure of liquid water, the BWI is able to integrate all the above factors into one observation at each grid point (Basist et al. 2001).

In this paper, we compare geo-referenced information of the BWI against precipitation over an area upstream of the gauging station. The GIS allows for the spatial delineation of the upstream area, using HydroSHEDS (Lehner et al. 2008) for a model of flow accumulation and direction. HydroSHEDS is a dataset in the public domain of conditioned Shuttle Radar Topography Mission (SRTM) elevation data (90m resolution) that used a series of processing steps that alter the elevation values in order to produce a surface that drains to the coast (except in cases of known internal drainages). Flow accumulation and flow direction grids (30 arc 
seconds) were downloaded at: http://gisdata.usgs.net/Website/HydroSHEDS/viewer.php and are available at: http://hydrosheds.cr.usgs.gov/dataavail.php. Since impoundments and/or diversions affect the amount and timing of water reaching the gauge, we used GIS to display the georeferenced dam data upstream of gauge stations, and exclude upstream watersheds with largescale obstructions (e.g. dams) on the basin.

\subsection{Estimation of Precipitation and runoff functions}

Two models relating the flow to the current and past BWI values are presented for each of the two basins. We regress the BWI values on the gauging station runoff per month (Equation 2) where $Q_{m(B W I)}$ is the discharge at a station for month $m$, and $n$ is number of previous months or lag months.

[2] $Q_{m(B W I)}=g(d)$,

where $d=\frac{\sum_{i=0}^{n} B W I_{m-n}}{n}$.

We investigate whether the lag periods improve the statistical correlation of the BWI and the gauging station runoff. Lagged runoff values are the average of the concurrent and the previous month(s). We suggest that the size, vegetative cover, soil type and topography of the catchments strongly influence the duration of the lag. In addition, snowmelt "captures" the accumulated precipitation and delays the flow, until the melting inside the snow pack "releases" the water, which can further increase the lag time. Moreover, since the BWI and precipitation model are based on one average value to represent the total area of accumulation, the size, slope and land surface characteristics all impacts the lag time.

Similar to Equation [2], we regress precipitation, $P$, of the basin on the gauging station runoff per month (Equation 3).

[3] $Q_{m(\text { Precip })}=f(d)$,

where $d=\frac{\sum_{i=0}^{n} P_{m-n}}{n}$.

The models developed in this study assume natural flow upstream of a gauging station. The physical model relates the water accumulated upstream to the magnitude of water received at the gauging station. Also, due to the spatial resolution of the satellite, it was best to restrict the 
study areas to be inland, which is at least 30 Kilometers from a large body of water, where the coastal boundary does not introduce noise in the results. Finally, with regards to the hydrological cycle, the basin must contain significant inter- and intra-annual variability of flow, in order to effectively use statistical relationships in the analyses.

\subsection{Estimating probabilities of extreme flow events}

Given the flow outputs from the flow and precipitation models, the Probability Distribution Function (PDF) describes the likelihood for an amount of flow to occur at a given time. This distribution makes it possible to provide statistics on the likelihood of low and high flow within a treaty basin. All parameters have been estimated, assuming a gamma distribution derived from the sample L-moments (Hosking 1990) using functions in the "Imomco" package (Asquith 2007) in the statistical software R (R Development Core Team 2008). In addition, the "lmomco" package is used to create $90 \%$ confidence intervals for the BWI derived from a Monte Carlo simulation. This PDF gives estimates for both low- and high-flow. Applying the PDF, a theoretical estimation of runoff can provide a probability of low flow, and, in the case of specific water requirements, this probability can be extended to estimate the probability of treaty noncompliance.

\section{Assessing the Performance of the Model}

\subsection{Basin selection}

The foundation of a defensible model has several necessary requirements that apply to the selection of gauge and satellite data (Table 1 includes a summary of these criteria and references) in order to select the basins. First, we refer to one of the leading datasets on international river basins, the Transboundary Freshwater Dispute Database (TFDD), which reports on 276 international river basins. Second, since this analysis focuses on the natural (unimpeded) flow model, watershed areas upstream of impoundments were excluded from the selection of calibration basins. The universe of unregulated international basins with available gauging station data is summarized for each watershed in the HydroSHEDS database using GIS. This includes dam location data (Food and Agricultural Organization on Africa Dams 2006; Meridian Global Dam Database 2006; and hydro power plants (CARMA 2009). In addition, the Global Lakes and Wetlands Database (Lehner and Döll 2004) identifies areas of large bodies of water (which usually have impoundments) within the international river basins. Basins with no geo- 
referenced dams upstream are loaded into Google Earth (version 5.2.1.1329) for further visual inspection of impoundments (where available, geo-referenced aerial photos are utilized). Third, we searched for available runoff data, from 1988 to present, in order to identify periods with records that overlapped with the over 24 years of the SSM/I instruments. Finally, basin size was another criteria. Particularly, the minimum basin size is $50,000 \mathrm{Km}^{2}$ so as to have a sufficient number of observations and adequate variation from the BWI to effectively identify the relationship between the satellite and gauge observations.

\subsection{The Basins}

We selected two international river basins that met the requirements of the model and had sufficient socio-economic and political data to draw on for application purposes: the Mekong and Zambezi. These basins represent two different scales of river length $(4,350 \mathrm{~km}$ and 2,574 km) and basin areas $\left(788,000 \mathrm{~km}^{2}\right.$ and $1,390,000 \mathrm{~km}^{2}$, respectively). These basins have a critical role in the socio-economic development of the riparian states including: food, water, transportation, electricity, natural resources, and cultural identity. Treaties govern both basins (TFDD 2008). Annex Table A1 summarizes and compares river basin statistics including: geographic and socio-economic variables. Estimates of relative changes (\%) in water flows (km3 yr -1) between 1960 and 1990 for the two selected basins compared to 2050s (Palmer et al. 2008) suggest a $1.0 \%$ for the Mekong and $-12.6 \%$ for the Zambezi. Due to the constraints of obtaining natural flow data, the sample areas are upstream sections of the river and represent nearly a quarter of the entire watersheds in their respective basins.

Data pertinent for the investigation of these two basins is derived from the Global Runoff Data Centre (GRDC), which provides available monthly time-series gauging station data in international river basins (approximately 3,500 stations). While the GRDC is the source of comprehensive data on global gauging station data, it should be noted that the data are available in limited time periods and the distribution of gauge data is not available across all countries; gauges are mainly located on main stem rivers in middle and high-income countries. For the comparison of the BWI and precipitation basin models, precipitation data are derived from the CRU 3.0 Global Climate dataset (2010), including data from 1901 to June 2006 (Mitchell and Jones 2005). These data have a spatial resolution of 0.5 degree. In the comparison of the Lower 
Mekong Basin flow estimates and precipitation, PRECipitation REConstruction over Land (PREC/L) (Chen et al. 2002) provides contemporary precipitation data.

\subsection{SSM/I derived surface wetness data description}

The BWI uses observations from the Special Sensor Microwave Imager (SSM/I). It is a sevenchannel passive microwave radiometer operating at four frequencies $(19.35,22.2,37.0$, and 85.05) and each channel has dual-polarization (except at $22.235 \mathrm{GHz}$ which is V-polarization only). The frequencies flown on the SSM/I are used to dynamically derive the amount of liquid water near the surface. Data are available from 1988 to present with the exception of some months in 1990 and 1991 (due to unresolved errors during that period from a failure in one of the satellite instruments).

\subsection{Calibration of the runoff models}

Linear and non-linear relationships are tested for the best fit between the independent variable and the dependent variable: the BWI and the flow, respectively. In order to account for the lag between the time when the water was received in the upper basin and the time it takes for the water to reach the downstream gauge, we performed several lagged relationships, realizing that the duration of the lag would depend on the basin's size, topography, soil type, and land-use. The lag occurs at monthly time steps. In other words, the BWI values were the average of current and previous month(s) values, and these were regressed against river flow data from a particular month. The results section highlights the best-lagged linear or non-linear relationships obtained from this process for both BWI and precipitation.

\section{RESUltS}

\subsection{General model}

This analysis includes tests of the accuracy, significance, and explanatory power of the precipitation and BWI models for each basin (Annex Tables A2, A3, and Table 2). The BWI has a superior lagged relationship, based on the Kinematic wave moving throughout the river basin. The accuracy of this relationship increased in the section where wetness values and gauge values were at the low end of their spectrum, which indicates that the wetness values can accurately measure the occurrences of low flow events. The lag in this area demonstrates the period of time 
that it takes for a prolonged dry period to translate into reduced flow downstream, or conversely, how long it will take for excessive precipitation to reach the gauge station downstream.

\subsection{Model results by basin}

\subsubsection{Zambezi}

The two estimated quadratic equations in $x$, following [2] and [3], for the Zambezi, are presented in Table 2 (two left columns). In comparing the models, the Zambezi BWI flow model (Table 2) has higher accuracy and significance (F-test) than the Zambezi precipitation model. The BWI model flow signature is clearly curved; it has a quadratic signature of high wetness values and extreme flow. High BWI values display considerable heteroscedasticity (from the studentized Breusch-Pagan test), which implies that numerous factors impact the high rate of flow past the gauge. In contrast, low BWI values (less than 1) contain a high confidence that the flow will be near the base flow. As a result, the BWI can be a quantitative indicator for periods and frequencies of flow associated with limited water - of particular relevance to obligations and commitments agreed upon in international water treaties. Due to its quadratic nature and no observations of wetness values below 0.5, the intercept is not realistic. Flow of 1.0 is around 300 $\mathrm{m}^{3} / \mathrm{s}$ averaged across a month at the gauging station.

The relationship of the gauge reading and BWI has a gamma distribution, i.e. there is a much higher probability that flow will occur in the low rate, however, the vast majority of the water moving through the basin occurs in the limited periods of high flow. Using the gamma distribution, this probability of predicted flow $(B W I=1.0)$ occurs approximately $25 \%$ of the time. Therefore, for the Zambezi River at the Katima Mulilo station, approximately 25\% of the time the flow is less than $300 \mathrm{~m}^{3} / \mathrm{s}$ averaged over the month (Figure 1.1-1.5, Annex Figure A1.1A1.4).

Since a strong correspondence between the wetness and gauge values is present, the wetness anomalies can be used to identify the probability of various levels of flow. In areas where there is skill in predicting the wetness levels, it can represent the functional form of the probability distribution, and help derive the return period of extreme events. The return period is a statistical measurement, denoting the average recurrence interval over an extended period of time. Predictive accuracy and high significance levels in the models also substantiates its value as a real time monitoring tool. 


\subsubsection{Mekong}

The two estimated quadratic equations in $x$, following [2] and [3], for the Mekong, are presented in Table 2 (two right Columns). The Mekong BWI flow model has nearly the same accuracy and significance as the Mekong precipitation model. The best correspondence occurred with a twomonth lag in both models. The best explanatory model has a non-linear relation. It also implies that predicted flow below 1,215 cubic meters per second (around BWI $=1.0$ ) is less frequent, since it occurs less than $25 \%$ of the time (Figure 2.1-2.5, A2.1-A2.4). Similar coefficients for both the linear and non-linear terms, which associate water near the surface with runoff, imply substantial robustness between each other. These results demonstrate the potential for applying the wetness values to river discharge in more generic applications across a broader range of river basins. The findings below further support this claim.

\subsection{Predicting runoff from currently available monthly BWI: Zambezi Case}

Since the SSM/I instrument is currently operational, it is possible to use the fitted model to predict recent runoff from monthly wetness values, beyond the calibration period. Due to the high accuracy and significance of the model, along with the longer period of record for the Zambezi, we chose to explore the ability of the BWI to predict seasonality, low flow (e.g. droughts), and high flow events (e.g. floods). This analysis was used to explore the utility of the model in serving as an early warning indicator.

The model for both river basins captured the seasonality of flow over their period of record. The Zambezi model identified and predicted a flood in 2010, which according to the model is slightly higher than the extreme flood of 2004 (Figure 3). Figure 4 displays the BWI anomaly for April 2010 in the Zambezi basin, where western Zambia has a large area that appears extremely wet, less than $5 \%$ of the time it is wetter (extremely wet anomalies are shown in purple). Floods on the Zambezi occur when heavy rains fall on the wetlands in Angola and Zambia. The water flows downstream and gets backed up at the Mambova fault. The river expands over the flat floodplain behind the fault until the waters meet the channel cut by the Chobe River in the south. During the annual flood, the buildup of water from the Zambezi River overcomes the Chobe, and water begins to flow south into Lake Liambezi. At the height of the flood, water occasionally flows directly into Lake Liambezi from the Zambezi River through the 
Bukalo Channel, as it did on May 8, 2010, which is the same month the BWI predicted the highest flow (NASA 2010).

These findings demonstrate that the model can be used to emulate intra and inter-seasonal

flows. Furthermore, findings illustrate the potential application of the BWI to predict extreme events in numerous basins around the world; when a model linking flow to the BWI is established.

\section{USE OF BWI FOR ECONOMIC AND INSTITUTIONAL ANALYSIS}

How can the results of the flow probability be utilized for policy purposes? We first discuss a framework to incorporate economic considerations for dealing with flows above and below normal (the long-term mean flow level that is the basis of the treaty). We then demonstrate how the data derived from the BWI not only helps estimate economic costs and losses due to extreme flow events but how such data could also assess the economic benefits states could reap should they be able to make use of such flow information in real time. This particular framework is applied to the Mekong and builds on Dinar A. (2009) and Houba et al. (2013). Due to space and readily available modeling framework that can be adjusted and applied for the Mekong, we demonstrate the application of the use of BWI for economic analysis using only the Mekong case. Future work will develop a model for the Zambezi and perform the same procedures.

International river basins, governed by treaties, are especially vulnerable if the treaties are connected to rigid institutions for the allocation of the basin water among the riparian states and the various sectors that use the water. This can be addressed, using a much broader set of options than those available through the treaty. The concept of 'strategic alliances' is proposed as the basis for a cooperative arrangement to address the impact of climate change on the stability of treaties. Finding a partner riparian with which to share the risk of a variable water supply is a strategic decision. To realize the need for strategic alliances the state has to assess the risk to the treaty, in terms of the flow probability. The flow probability is derived from the BWI calculations as demonstrated in the previous sections.

Assume a basin that is shared by $N$ riparian states. Each state has different water resources it may use on its territory, in addition to the shared basin. The water in the basin is allocated between the $N$ riparian states, based on an existing treaty that was previously signed between these states. As is the case in most treaties, water is allocated in a fixed proportion 
between the riparians (Wolf et al. 1999, Kilgour and Dinar, 2001). Water is used for joint projects (e.g., hydropower production, environmental flows), and/or used unilaterally on each riparian territory (e.g., for irrigation, hydropower, urban supply). For our discussion it is not important how water is used beyond the allocation stage. For simplicity, assume that only annual flows are the subject of the allocation.

Once a riparian state is faced with a given allocation, investments (infrastructure and domestic allocations among sectors) are made and the entire water system is designed to meet the given allocation. Changes to the original basin allocation are difficult to accommodate by the riparian states in the short run because they necessitate altering fixed infrastructure assets and regulations, both of which are associated with high costs. Therefore, flow variability may pose harm to the basin riparian states. In the following sections we propose a framework that utilizes the estimated flow probability to assess possible arrangements among the riparian states, based on their relative advantages. We start with a deterministic world to establish the relationships we need, and then move to the stochastic world, using the BWI probabilities.

\subsection{A deterministic world}

Assume that annual flow in the shared basin is $F\left(\mathrm{~km}^{3} /\right.$ year) and that the treaty allocates this flow in full between the $N$ riparian states (environmental flows are not assigned any allocation). Since treaties refer to long term annual flows, $F=\bar{F}$, where $\bar{F}$ is the long-term mean annual flow in the shared basin. Let $f_{i}$ be the annual allocation of water in the shared basin to riparian $i, i \in N$; $\sum_{i \in N} f_{i} \leq F$. Each riparian then allocates the water internally/domestically among competing uses (sectors, regions), using their own criteria. Let $f_{i j}^{d}, j=1,2, \ldots, J ; J=\{$ households and industry, hydropower generation, irrigated agriculture, fishery $\}$, be the internal use of state $i$ 's allocation from the shared basin, with $\sum_{j=1}^{J} f_{i j}^{d} \leq f_{i} ; \forall i \in N$; where $d$ stands for domestic allocation. Assume that water production functions for each use are known in each riparian state. Each riparian state has a payoff function from its internal use of its basin allocation, given the treaty parameters that are based on the long-term mean flow $v_{i}=\sum_{j=1}^{J} h_{j}^{i}\left(f_{i j}^{d} \mid F\right), \forall i \in N$. 
Assume further that each riparian state has also other resources of, say, capital $(x)$ and water $(w)$ that are outside the shared basin and are used for economic activities in regions other than the shared basin. The production functions of these resources are also known, and the state's payoff function is $u_{i}=\sum_{j=1}^{J} k_{j}^{i}\left(x_{i j}^{d}, w_{i j}^{d}\right), \forall i \in N$. A state is a rationale decision maker and maximizes its payoff over its own resources. Therefore, a state payoff $(C)$ is:

$$
C_{i}=\operatorname{Max} \sum_{j=1}^{J}\left\{h_{j}^{i}\left(f_{i j}^{d} \mid \theta F\right)+k_{j}^{i}\left(x_{i j}^{d}, w_{i j}^{d}\right)\right\}, \forall i \in N
$$

Subject to:

[4a] $\quad \sum_{j=1}^{J} f_{i j}^{d} \leq f_{i} ; \forall i \in N$

[4b] $\quad \sum_{j=1}^{J} x_{i j}^{d} \leq X_{i}^{d}, \forall i \in N$

[4c] $\quad \sum_{j=1}^{J} w_{i j}^{d} \leq W_{i}^{d}, \forall i \in N$.

For simplicity assume that only these constraints are considered in the optimization problem of state $i$.

The basin riparian states have incentives to cooperate. The treaty among the riparian states is one type of cooperation, which is based on agreement of a formula to allocate the flow in that basin between them. The basin-wide profit $B$ is:

$$
B=\operatorname{Max} \sum_{i \in N} \sum_{j=1}^{J}\left\{h_{j}^{i}\left(f_{i j}^{d} \mid \bar{F}\right)+k_{j}^{i}\left(x_{i j}^{d}, w_{i j}^{d}\right)\right\}
$$

Subject to:

[5a] $\quad \sum_{i=1}^{N} f_{i} \leq \bar{F}$

[5b] $\quad \sum_{j=1}^{J} f_{i j}^{d} \leq f_{i} ; \forall i \in N$ 
[5c] $\quad \sum_{j=1}^{J} x_{i j}^{d} \leq X_{i}^{d}, \forall i \in N$

[5d] $\quad \sum_{j=1}^{J} w_{i j}^{d} \leq W_{i}^{d}, \forall i \in N$.

For simplicity, assume that only these constraints are effective in the optimization problem of the basin and various cooperative agreements between subsets of states in the shared basin. Note that it would be straightforward to define the payoffs of cooperation for any coalition of states $n \subseteq N$, where $n$ includes a subset of all the riparians $N$ of the shared basin, and perform cooperative game theoretic analyses as advocated in e.g. Dinar A. (2009)

The model in [5]-[5d] suggests that $\bar{F}, X$, and $W$ are the resources that affect the potential payoff in the basin. Remember that $\bar{F}$ is a joint resource while $X$ and $W$ are resources owned individually by each riparian state. In case the treaty only partly covers the basin, as is the case in our application to the Mekong, then $\bar{F}$ refers to the treaty and $X$ and $W$ to resources outside the treaty. In the case where the main issue in the treaty is the shared basin flow, $\bar{F}$, then, in most cases, if not in all known treaties, the riparian states cooperate only over the water resources that flow.

\subsection{Introducing Flow Variability Considerations}

Assume that flow in the domestic basins is deterministic, (by deterministic flow we mean a flow distribution that is below a given variance) and that the flow in the international basin is variable. (The analysis is similar in the case that domestic basins face variability too, but is easier to demonstrate with only the shared basin facing variable flow.) Let the flow variability be represented by a probability of occurrence of a state of nature (flow level) that is expressed as a departure from the annual mean, $\bar{F}$. We measure variability by $\theta$, which has a probabilistic distribution calculated from the BWI analysis earlier in the paper and $\theta \bar{F}$ obtains values across the range of flow in the basin over time. When the flow greatly exceeds the long-term mean annual value $\bar{F}$, it may lead to damage or loss from floods and the inability to capture all the water. When the flow is much below $\bar{F}$ there is damage from crop loss, restricted water resources, treaty conflict, as well as energy underproduction. Therefore, $h$, the damage from variable flow, can be approximated by an U-shaped function of $\theta$. 
The basin-wide profit $B$ is now:

[6] $\quad B_{\theta}=\operatorname{Max} \sum_{i \in N} \sum_{j=1}^{J}\left\{h_{j}^{i}\left(f_{i j} \mid \theta \overline{\mathrm{F}}\right)+k_{j}^{i}\left(x_{i j}^{d}, w_{i j}^{d}\right)\right\}$

Subject to:

[6a] $\quad \sum_{i=1}^{N} f_{i} \leq \theta \bar{F}$

[6b] $\quad \sum_{j=1}^{J} f_{i j}^{d} \leq f_{i} ; \forall i \in N$

[6c] $\quad \sum_{j=1}^{J} x_{i j}^{d} \leq X_{i}^{d}, \forall i \in N$

[6d] $\quad \sum_{j=1}^{J} w_{i j}^{d} \leq W_{i}^{d}, \forall i \in N$,

and various cooperative agreements between subsets of states in the shared basin.

As mentioned for the deterministic case, for any coalition of states $n \subseteq N$, where $n$ includes a subset of all the riparians $N$ of the shared basin, one can define the expected payoff of cooperation, denoted as $s_{n}\left(\theta \bar{F}, \sum_{k \in n \subseteq N} X_{k}, \sum_{k \in n \subseteq N} W_{k}\right)$. Then, for the grand coalition $N$ $s_{N}\left(\theta \bar{F}, \sum_{k \in N} X_{k}, \sum_{k \in N} W_{k}\right)=B_{\theta}$

Following Just and Netanyahu (1998), and due to the basin-level externalities resulting from the variation in water supply, $\left|\frac{\partial s_{n}}{\partial \theta}\right| \leq\left|\frac{\partial s_{N}}{\partial \theta}\right|$. This will drive the basin riparians to seek solutions resulting from water supply variations in partial coalitions rather than the grand coalition. They must then rely on resources that exist outside the basin that may also be subject to variable water supply conditions.

\subsection{Application to the Mekong Basin}

We present here a modified version of the empirical model used in Houba et al. (2013). The interested reader can find the original model equations and specifications in the Online 
Appendices A and B of Houba et al. (2013). While Houba et al. (2013) was interested in demonstrating how non-cooperation or cooperation might evolve in the year 2030, we focus in this analysis on the implications of the distribution of the BWI expressed over the range of flow probabilities as measured at the gauging station Chiang Saen in Thailand. We extrapolate benefits from a given vector of flows at Chiang Saen on the main stream Mekong (this extrapolation is substantiated later in the article) with estimated probabilities, and rainfall in the Lower Mekong Basin (LMB) tributaries. Finally, these probabilities are used to calculate the expected value of basin benefits under various climatic scenarios.

\subsubsection{Description of the model}

The model is based on a simplified hydrological structure of the basin with water flow from the upper Mekong Basin (China) to the LMB and the distinction between the mainstream and tributaries in the LMB. The LMB is further subdivided into the Tonle Sap and the Delta (estuary), as seen in Figure 5.

Basin-wide water availability is determined by water flow from China to the LMB, through Chiang Saen gauging station, and by precipitation in the tributaries of all LMB states. Water uses are aggregated in each sub region of the model into (1) industry and households, (2) hydropower generation, (3) irrigated agriculture, and (4) fisheries. Navigation is not included due to the fact that many parts of the basin are unnavigable. Water quality is measured in terms of salinity in Houba et al. (2013). In this paper we assume that salinity impacts fishery and irrigated agriculture. Hydropower generation is considered to be an in-flow user.

Unlike in Houba et al. (2013), we do not allow the model to consider investment in new dams and new irrigation. We refer to the existing dams and the existing irrigated area on the Mekong mainstream and tributaries. According to Houba et al. (2013) the building costs of existing dams and irrigation infrastructure are sunk. The existing dams in China are all built in the mainstream of the Mekong, as a cascade of reservoirs, while all existing dams in the LMB are located on its tributaries. This difference will affect the way water flow is modeled. Therefore, we refer to the current situation (data from 2010), and fluctuations in water flow and precipitation that affect economic performance of the basin economy. A reservoir on tributary A cannot reuse water from a dam on tributary B and vice versa. But water entering the first reservoir of a cascade can be reused and stored, over time, in all downstream reservoirs. 
The model is a static one, with an annual setup, represented by two seasons (wet and dry) and several locations in the basin (UMB, LMB, mainstream, tributaries, Tonle Sap, and Delta). The original model was calibrated by Houba et al. (2013) to conditions in 2010. All modifications introduced in this paper comply with the original calibration. The water inflow for the mainstream of the LMB consists solely of the outflow received from China. Reservoirs/dams are filled in the wet season and the water is used during the dry season. During the wet season the Mekong water in UMB (China) can be used for industrial and household activities, fish production, storage (subject to evaporation) for use in the dry season, and non-consumptive hydropower generation. In addition to the wet season water use activities, dry season water use activities include also irrigation. While the mainstream LMB is modeled similarly to the UMB (China), it does not take into consideration water use by industry and households. Water flow in the tributaries of the LMB is due mostly to precipitation in the LMB region. Existing dams on tributaries are modeled in a similar way as was described for China's mainstream dams. In the wet season, the outflow from mainstream UMB and tributary dams inundates wetlands and the Tonle Sap, nurturing fish reproduction, and flushing salinity in the estuary (Delta).

Following Houba et al. (2013) the benefit, cost and loss functions in the model are quadratic, with the benefit function being concave (same as the flow parameters in the BWI model) and the cost and loss functions being convex to the origin. Benefit functions were used for industry and households, hydropower generation, irrigated agriculture, and fisheries. These functions are straight forward and can be found in Houba et al. (2013). The value function of the Tonle Sap and Delta/Wetlands assumes that all fishery production concentrates in that lake and surrounding wetlands. Salinity losses are modeled only in the LMB agricultural sector. The volume of water that enters the Tonle Sap and then flows out into the Delta wetlands is a linear function of the flow in the river in the dry and wet seasons (Houba et al., 2013).

\subsubsection{Applying the BWI to the Mekong Economic Model}

The geography/hydrology of the Mekong is such that the Upper Mekong and the Tributaries of the Lower Mekong produce the main inputs of water into the basin. Flow from the Mekong upper basin was calibrated to the BWI, by using gauge values at Chiang Saen. This regression equation is used as a hydrological model. Even though the upper and lower basins have

appreciably different geographies, sizes, and rainfall: nonetheless, we applied the upstream 
hydrological model to the lower basin. Our assumption in doing so is that the BWI signal is designed to detect liquid water from all sources, and measures the percentage of the surface that is liquid water. Therefore, we can still use the calibrated flow model to detect that amount of water moving through the lower basin. Our hypothesis is that BWI values, which are a measure of liquid water near the surface, are a robust signal and the model parameters could effectively transcend different geographies.

There was the possibility of shifting the intercept, since the lower basin is appreciably larger, and therefore its base flow should be higher. However, we wanted to minimize any tuning, in order to test the robustness of the model. Therefore the following change was made; the lag was reduced from two to a one month accumulated lag, which would allow for better integration of the flow from the upper basin reaching the lower basin. This, in turn, would allow us to model the flow as one kinematic wave.

In order to weigh the basin by magnitude of water moving through the entire basin, the upper and lower basins were weighed in terms of their area (the large lower basin is a much larger area, and therefore higher weights). This allowed us to calculate the integrated flow from the upper and lower basins into one combined flow value for the two basins. Since the upper basin has a two-month lag, the first two months of 1988 and 1992 were set to be missing. A simple interoperation technique could easily and effectively be applied, since the beginning in the year is not a critical period of flow, however we did not apply it in order to minimize assumptions.

The average flow was derived from the BWI values and the model parameters over the period of record, in terms of cubic meters/second. We converted the flow from cubic meters/second to cubic kilometers/year. The final number is 424 cubic kilometers, which is reasonably close to the independent assessments of annual mean flow on the Mekong, which range from 410 (Houba et al., 2013) to 475 (Mekong Water Commission 2009). To keep our economic optimization comparable with previous work we express water in cubic kilometers per year rather than in cubic meters per second ( 1 cubic meters per second $=0.031556926$ cubic kilometers per year).

We were very encouraged by the fact that the flow numbers derived through the BWI wetness values were congruent with the expected flow values. Equally important, the monitored 
variation of flow from month to month, and year to year was accurately captured by the BWI values. For example, the major flood of 2000 was clearly identified and the BWI provided a onemonth lead time to the magnitude of the flood, allowing time to mitigate its consequences. Equally important, the major drought of 2010 was also identified and once again the BWI provided an early warning about the magnitude of the drought, allowing critical time to mitigate its consequences. These findings clearly show the robustness of the flow model, and its utility to measure inter-annual variability, the cumulative density function of flow probability, and the standard deviation of flow over a record of 25 BWI values.

We performed a similar analysis using precipitation inputs to predict mean annual flow for the Mekong. Specifically, we used the flow model parameters derived from the upper basin and applied them to the LMB, in order to determine integrated flow for the River as a whole. The calculated flow based on rainfall is 359 , while the BWI provided a value of 424 cubic kilometers per year (i.e. the BWI value is much closer to the consensus of the mean annual flow). The results for the LMB tributaries are presented in Annex Table A4. This result was surprising, since the precipitation model had a slightly better explanatory power of flow in the upper basin. We interpreted this finding as demonstrating the robustness of the wetness index, and the ability to apply the model in areas outside of the region where they are calibrated. Consequently, we use the BWI flow predictions in our application of the LMB tributaries for the economic model (Table 3).

\subsubsection{The Assumptions in the Economic Model}

We assume that the water availability in the wet and dry season in the Mekong can be approximated as a ratio of 7:1 (Houba et al., 2013, based on Ringler et al., 2004). We apply this ratio to the annual flows of both the mainstream UMB in China and the tributaries of the LMB. We use data from 2010 (which was a major drought year) for economic values and for water availability in the LMB tributaries (Houba et al., 2013: Table 1, Pg. 100). We use the BWI values reported earlier (Annex Table A3) to simulate the flow variability in the Chiang Saen gauging station. The mean flow of $2,416 \mathrm{~m}^{3} / \mathrm{sec}$ and the standard deviation of 1534 are converted to $76.271 \mathrm{~km}^{3} /$ year and $48.408 \mathrm{~km}^{3} /$ year, respectively, to conform to the units in Houba et al. (2013). Having a mean flow value very close to the one used by Houba et al. (2013), 80.126

$\mathrm{km}^{3} /$ year, allows us to use the calibrated values of that model. For the LMB tributaries we use 
the previously estimated mean and SD of 429.623 and $84.087 \mathrm{~km}^{3} /$ year, respectively, which was very close to that used by Houba et al. (2013), which is $410.650 \mathrm{~km}^{3} /$ year.

The performance of the economies in the Mekong Basin is simulated under four water flow scenarios that span over the range of flow values observed/simulated and their calculated probabilities suggested by the BWI. Due to the skewed flow distribution in the Chiang Saen (Figure 2.4) and in the LMB tributaries (Annex Figure A3) we refer to flow values of the mean: plus and minus 1SD and 2SD. The corresponding flow levels of the UMB and LMB tributaries and their probabilities (taken from Annex Figure A2.3 and Annex Figure A3, respectively) are presented in Table 3.

Another modification to the application by Houba et al. (2013) that we implemented is to model the LMB as having weak governance only. Weak governance means that the riparian countries are not well organized and do not obey the regulations imposed by the Mekong River Commission (MRC). This is a good representation of the present situation in the LMB, where for example (the Economist, 2013) Laos, with financial support from Thailand, in need for electricity, is constructing the first (Xayaburi Dam) of nine big dams. This unilateral action in the LMB goes against the MRC, which is powerless to block the unilateral action of Laos. Altough there are strong protests from important Commission members, Cambodia and Vietnam.

\subsubsection{Results of the Economic Model}

We ran four scenarios, following the pairs $\left(a_{i} ; b_{i}, i=1, \ldots, 4\right)$ of flow values we derived from Table 3, which correspond to distribution of the flow in both the UMB and the LMB tributaries. As can be seen from Table 3, the distribution of the LMB tributaries flow is much more skewed towards lower values (drought) than the flow of the UMB. Detailed results are presented for the case of mean flows only (See Annex Table A5 for results representing all flow range).

Table 4 presents the water balances for both regions at the wet and dry seasons. As is apparent from Table 5, the net welfare generated in the UMB is $\$ 2.656$ billion and that of the LMB is $\$ 6.663$ billion, annually. Of the net welfare produced annually in the UMB, hydropower comprises $31 \%$, irrigation $45 \%$, fisheries $9 \%$ and households and industry $15 \%$. For the LMB the values are $3 \%, 27 \%, 41 \%$, and $30 \%$, respectively. Table 5 also suggests that the damage from salinity due to seawater intrusion in the LMB is 0 for mean flow or above mean flow runs. However, losses of $\$ 3.133$ billion are encountered in the LMB in the case of the below mean 
flow run. It appears that the LMB is much more sensitive to flow fluctuations than the UMB. This is also apparent from Figure 6. Both high and low levels of flow have a negative impact on net welfare of the basin. Such difference in sensitivity to flow level by the LMB could be taken into account in future negotiations over a possible basin-wide agreement.

Using the probabilities in Table 3 and the net benefits in Figure 6 we calculated the expected total basin net benefit value at $\$ 6.359$ billion. This figure represents only $68 \%$ of the basin-wide net benefits ( $\$ 9.313$ billion) that was estimated under the mean flow. Having the flow distribution information (as provided by the BWI) allows the basin riparians to reconsider arrangements that will secure their economies rather than face significant losses under extreme flow situations.

\section{USE OF BWI FOR RESEARCH ON CONFLICT AND COOPERATION OVER WATER}

In addition to its economic applications, analysts and academics can use the BWI to further explore the relationship among water, conflict, and cooperation. To date, scholars in the socalled field of hydro-politics have largely used national measures of water availability per capita as well as precipitation and drought indices to explore how physical water scarcity affects interstate conflict (Toset et al. 2000; Hensel et al. 2006; Gleditsch et al. 2006). A similar methodology has been used by scholars investigating inter-state cooperation over water (Brochmann and Hensel 2009; Tir and Ackerman 2009; Dinar et al. 2011). Most recently, scholars have also considered the role of water flow variability across time on hydro-political relations between states (e.g. Dinar et al. 2010; Dinar et al. 2012; De Stefano et al. 2012).

Given some of its advantages the BWI provides another measure of flow that scholars can utilize in their socio-political studies. In particular, the data provided by the BWI befit recent calls by scholars for better measures of "dynamic scarcity," which make better use of satellite imagery and meteorological data, to account for time-varying measures of water availability (Buhaug et al. 2008).

Specifically, various studies currently use the TFDD Basins at Risk (BAR) events dataset to make particular arguments about conflict and cooperation over water as reflected in countries' water-related cooperative/conflictive exchanges and interactions (Wolf, Stahl \& Macomber 2003; Yoffe at al. 2004; Stahl 2005). Application of the BWI can be used to ascertain how 
physical phenomenon (such as droughts and floods) interacts with political, economic, and social variables.

To demonstrate the utility of the BWI for the type of socio-political research discussed above, we investigate the relationship between extreme events and water-related political events. In particular we explore how floods and droughts (identified by the BWI) are specifically related to BAR score values. Annex Table A6 documents variability from the mean water flow per month ( $\mathrm{m}^{3} /$ second per month) for the period April 1988 through December 2005 for the Zambezi and April 1988 through December 1993 for the Mekong (we could not find consistent data for other years in the two basins). We then use the data from the BAR dataset to count the number of water-related complaint events and provide their associated BAR score per each month for which they exist. Annex Table A6 also presents the months for which we were able to match the water flow and the BAR data. Past research suggests that the higher the difference between the longterm flow in the river (which is the basis for the treaty allocation) the more conflictive (or less cooperative) behavior would be detected among the riparian states (Stahl, 2005). Therefore, we estimate the correlation between the event that took place in a given month and the level of water flow during that month.

To do that we regress the BAR score on the change in water flow from the mean, separately for the Zambezi and for the Mekong. We obtained a correlation of -0.35 for the Zambezi and a correlation of -0.71 for the Mekong. We ran a linear Poisson regression to estimate the effect of flow variability on the BAR score (a count variable). We could not find a significant difference between the Zambezi and the Mekong (a dummy for the Mekong and Zambezi was insignificant).

The results of the regression of the BAR values and flow variability are presented in Table 6. The right panel presents an equation that attempts at distinguishing between the Zambezi and the Mekong by introducing a dummy variable for the basin. The left panel presents an equation that doesn't distinguish between the basins. The flow variability coefficient is negative and significant. The results (left panel) should be interpreted as follows: a change of $+1000 \mathrm{~m}^{3} / \mathrm{s}$ per month (floods) of flow from the mean reduces the BAR scale by 0.765 units. A change of $-1000 \mathrm{~m}^{3} / \mathrm{s}$ per month (drought) increases the BAR scale by 0.765 units. These results are similar to the finding in Dinar et al. (2011) where a positive correlation was found between 
water scarcity levels and cooperation in the range of scarcity values, which are observed in bilateral treaties.

Although only utilized for illustrative purposes and representing a very small sample of basins, these results indicate that reduced flow from the mean induces more (extensive) cooperative behavior while an increased flow from the mean induces less (extensive) cooperative behavior. The focus is on cooperative events (rather than conflictive events) because all BAR events associated with these two basins, observed within the time frame under consideration, were largely cooperative, and the average BAR score for the two basins was thus positive. More generally, this illustrative exercise demonstrates that the BWI data may be used as another measurement of variability, extreme events, and/or scarcity in socio-political research on water, conflict, and cooperation.

\section{Concluding Discussion}

The natural runoff data derived from the BWI for the years 1988-2013 (and subsequently onward) can provide similar, and more accurate, measurements of flow variability data, compared to other predictive indices: such as precipitation. The BWI may be used to assess the historical and future impact of flow variability on international river basins. In river basins that are already governed by international treaties, policy makers may likewise use the data to assess the impact of flow variability on international river basin treaty stability or use the data to negotiate appropriate treaty mechanisms to deal with the expected variability, which may result in devastating extreme events. Such preparedness is crucial if countries wish to mitigate the economic, social, and political effects of flow variability.

The determination of water distribution and overall water supply variability must be based on the supply entering the basin. In particular, results from this paper demonstrate that the BWI and precipitation runoff models did have a highly significant explanatory power of downstream gauge measurements. However the BWI model has higher accuracy and significance levels compared to the precipitation model in the Zambezi, while a negligible difference exists in the Mekong. Moreover, the accuracy of the BWI increased under low flow conditions, which reveals its utility for drought monitoring. This allows it to serve as an independent measure of risk, along with the probability of occurrence. Specifically, the BWI-based model accurately predicted the magnitude of floods a month or two in advance. It accomplished this result by 
measuring the magnitude of water entering the watershed upstream, and combines the measurements with the inflow in the lower basin. This could be a valuable tool for monitoring and mitigating the adversity associated with impending extreme events in the lower basin, where the majority of the impact is usually experienced.

Building on the results from this study, future work will refine the methodology and applications. Specifically, the methodology can be extended beyond the stringent set of assumptions presented in this paper, thereby allowing policy makers to monitor flow in regulated rivers. In addition, analogues from the gauge data currently available can be developed. This could allow one to appropriately apply the model parameters to local BWI data and to a target basin. We demonstrate the robustness of the model parameters, by successfully applying the model parameters developed for the upper basin to the entire river basin. This analogue approach would allow the analysts to obtain the relative distribution of flow, thereby comparing the probability distribution of extreme events in the analogue and target basins. Future work will also seek to derive systematic flow data for the entire spectrum of 276 international river basins that are often under investigation in cross-national hydro-political studies. The utility of such data is already apparent in application to studies in conflict and cooperation over shared river resources. 


\section{ACKNOWLEDGEMENTS}

We acknowledge the Global Runoff Data Center for providing us with runoff data for the two basins. This paper was funded in its initial stages by the World Bank Knowledge for Change Project (KCP). We also thank our respective institutions for their support: Weather Predict, the Water Science and Policy Center at University of California Riverside, Florida International University, and World Bank Research Group. Shlomi Dinar would also like to acknowledge a grant from the Smith Richardson Foundation that aided with research that is used in this report. The views expressed in this paper are those of the authors and should not be attributed to their respective institutions. 


\section{REFERENCES}

Asquith, W. H. (2007), lmomco: L-moments, Trimmed L-moments, L-comoments, and Many Distributions, R package version 0.84 .

(BAR) Basins at Risk, Transboundary Freshwater Dispute Database. Available at http://www.transboundarywaters.orst.edu/research/basins_at_risk/. Accessed 1 January 2011.

Basist, A., Grody, N. C., Peterson, T. C., and Williams, C. N. (1998). "Using the Special Sensor Microwave / Imager to Monitor Land Surface Temperatures, Wetness, and Snow Cover," Journal of Applied Meteorology, 37(September): 888-911.

Basist, A., C. Williams Jr, T. F. Ross, M. J. Menne, N. Grody, R. Ferraro, S. Shen, and A. T. C. Chang (2001), Using the Special Sensor Microwave Imager to monitor surface wetness, Journal of Hydrometeorology, 2(3), 297-308.

Bates, B.C., Z.W. Kundzewicz, S. Wu and J.P. Palutikof, Eds. (2008), Climate Change and Water. Technical Paper of the Intergovernmental Panel on Climate Change, IPCC Secretariat, Geneva, $210 \mathrm{pp}$.

Blankespoor, B., A. Basist, A. Dinar and S. Dinar (2012), Assessing Economic and Political Impacts of Hydrological Variability on Treaties: Case Studies of the Zambezi and Mekong Basins Policy Research Working Paper No. 5996, 1-56 pp, World Bank, Washington, DC.

Brochmann, M., and P. Hensel (2009), Peaceful Management of International River Claims, International Negotiation, 14(2), 393-418.

Buhaug, H., N. P. Gleditsch, O. M. Theisen (2008), Implications of Climate Change for Armed Conflict, The Social Development Department, World Bank.

(CARMA) Carbon Monitoring for Action (2009), http://carma.org/ Also, see: D. Wheeler and K. Ummel (2008), Calculating CARMA: Global Estimation of CO2 Emissions from the Power Sector - Center for Global Development Working Paper 145.

Chen, M., P. Xie, J. E. Janowiak, and P. A. Arkin (2002), Global land precipitation: A 50-yr monthly analysis based on gauge observations, Journal of Hydrometeorology, 3(3), 249266. 
(CRU) Climate Research Unit (2010), Global Climate version 3.0, Downloaded from http://badc.nerc.ac.uk/data/cru/.

Dai, A., T. Qian, K. E. Trenberth, and J. D. Milliman (2009), Changes in Continental Freshwater Discharge from 1948 to 2004, Journal of climate, 22(10), 2773-2792.

De Stefano, L., J. Duncan, S. Dinar, K. Stahl, K. M. Strzepek, and A. T. Wolf (2012), Climate change and the institutional resilience of international river basins, Journal of Peace Research, 49(1), 193-209.

Dinar, A., B. Blankespoor, S. Dinar, and P. Kurukulasuriya (2010), Does precipitation and runoff variability affect treaty cooperation between states sharing international bilateral rivers?, Ecological Economics, 69(12), 2568-2581.

Dinar, S. (2009), Scarcity and Cooperation Along International Rivers, Global Environmental Politics, 9(1), 109-135.

Dinar, A. (2009), Climate Change and International Water: The Role of Strategic Alliances in Resource Allocation, in Policy and Strategic Behaviour in Water Resource Management, edited, EarthScan, London.

Dinar, S., A. Dinar, and P. Kurukulasuriya (2011), Scarcity and Cooperation along International Rivers: An Empirical Assessment of Bilateral Treaties, International Studies Quarterly, $55(3), 809-833$.

Dinar, S., D. Katz, L. De Stefano, and B. Blankespoor (2012), Climate change, conflict, and cooperation: Global analysis of the resilience of international river treaties to increased water variability, in EU CLICO-sponsored Rethinking Climate Change, Conflict and Security Conference, edited, University of Sussex, United Kingdom, 18-19 October.

Drieschova, A., M. Giordano, and I. Fischhendler (2008), Governance mechanisms to address flow variability in water treaties, Global Environmental Change, 18(2), 285-295.

Drury, A. C., and R. S. Olson (1998), Disasters and Political Unrest: An Empirical Investigation, Journal of Contingencies \& Crisis Management, 6(3), 153.

(FAO) Food and Agricultural Organization (2006), The Africa Dams Database. http://www.fao.org/geonetwork/srv/en/metadata.show?id=38077 
Gleditsch, N. P., K. Furlong, H. Hegre, B. Lacina, and T. Owen (2006), Conflicts over shared rivers: Resource scarcity or fuzzy boundaries?, Political Geography, 25(4), 361-382.

The Global Runoff Data Centre (2008), 56068 Koblenz, Germany.

Hendrix, C. S., and I. Salehyan (2012), Climate change, rainfall, and social conflict in Africa, Journal of Peace Research, 49(1), 35-50.

Hensel, P. R., S. McLaughlin Mitchell, and T. E. Sowers (2006), Conflict management of riparian disputes, Political Geography, 25(4), 383-411.

Herold, C., and F. Mouton (2011), Global flood hazard mapping using statistical peak flow estimates, Hydrology and Earth System Sciences Discussions, 8(1), 305-363.

Hosking, J. R. M. (1990), L-moments: analysis and estimation of distributions using linear combinations of order statistics, Journal of the Royal Statistical Society. Series B (Methodological), 105-124.

Houba, H., Kim Hang Pham Do, and X. Zhu (2013), Saving a river: a joint management approach to the Mekong River Basin, Environment and Development Economics, 18(Special Issue 01), 93-109.

(IPCC) Intergovernmental Panel on Climate Change (2001), Climate Change 2001: Impacts, Adaptation, and Vulnerability, Contribution of Working Group II to the Third Assessment Report of the Intergovernmental Panel on Climate Change. Cambridge: Cambridge University Press.

(IPCC) Intergovernmental Panel on Climate Change (2007), Intergovernmental Panel on Climate Change Fourth Assessment Report, Climate Change 2007: Synthesis Report, Summary for Policymakers.

Jury, W. A., and H. Vaux (2005), The role of science in solving the world's emerging water problems, Proceedings of the National Academy of Sciences of the United States of America, 102(44), 15715-15720.

Just, R., and S. Netanyahu (1998), International Water Resource Conflicts: Experience and Potential, in Conflict and Cooperation on Trans-Boundary Water Resources, edited by R. Just and S. Netanyahu, Kluwer, Norwell, MA, USA. 
Kabat, P., R.E. Schulze, M.E. Hellmuth, and J.A. Veraart (eds). (2002) Coping with Impacts of Climate Variability and Climate Change in Water Management: A Scoping Paper. DWCReport no. DWCSSO-01, International Secretariat of the Dialogue on Water and Climate, Wageningen.

Kilgour, D. M., and A. Dinar (2001), Flexible Water Sharing within an International River Basin, Environmental and Resource Economics, 18(1), 43-60.

Lehner, B., and P. Döll (2004), Development and validation of a global database of lakes, reservoirs and wetlands, Journal of Hydrology, 296(1-4), 1-22.

Lehner, B., K. Verdin, and A. Jarvis (2008), New global hydrography derived from spaceborne elevation data, EOS, TRANSACTION, American Geophysical Union, 89(10), 93-104

McCaffrey, S. C. (2003), The Need for Flexibility in Freshwater Treaty Regimes, Natural Resources Forum, 27, 156-162.

Mekong River Commission (2009), The flow of the Mekong, Mekong Water Commission $\begin{array}{llll}\text { Information } & \text { Booklet } & \text { Series, } & \text { No. }\end{array}$ http://www.mrcmekong.org/assets/Publications/report-management-develop/MRC-IMNo2-the-flow-of-the-mekong.pdf.

Meridian World Data (2006), Meridian Global Dam Database. http://www.meridianworlddata.com/

Miller, K., and D. Yates (2006), Climate change and water resources: a primer for municipal water providers, 83 pp., American Water Works Research Foundation and UCAR, Denver, CO.

Milly, P., J. Betancourt, M. Falkenmark, R. M. Hirsch, Z. W. Kundzewicz, D. P. Lettenmaier, and R. J. Stouffer (2008), Stationarity is dead: whither water management?, Science, 319(1 February), 573-574.

Mitchell, T. D., and P. D. Jones (2005), An improved method of constructing a database of monthly climate observations and associated high resolution grids, International journal of climatology, 25(6), 693-712.

NASA (2010), Flooding on the Zambezi River: Natural Hazards, edited, NASA, http://earthobservatory.nasa.gov/IOTD/view.php?id=44132. 
Nel, P., and M. Righarts (2008), Natural Disasters and the Risk of Violent Civil Conflict, International Studies Quarterly, 52(1), 159-185.

Palmer, M. A., C. A. Reidy Liermann, C. Nilsson, M. Flrke, J. Alcamo, P. S. Lake, and N. Bond (2008), Climate change and the world's river basins: anticipating management options, Frontiers in Ecology and the Environment, 6(2), 81-89.

Peduzzi, P., H. Dao, C. Herold, and F. Mouton (2009), Assessing global exposure and vulnerability towards natural hazards: the Disaster Risk Index, Natural Hazards Earth System Science, 9, 1149-1159.

R Development Core Team (2008), R: A language and environment for statistical computing, reference index version 2.7.2. Copyright (C) $2008 \mathrm{R}$ Foundation for Statistical Computing, Vienna, Austria. Retrieved from http://www.R-project.org. ISBN 3-90005107-0.

Salehyan, I. (2008), From Climate Change to Conflict? No Consensus Yet, Journal of Peace Research, 45(3), 315-326.

Stahl, K. (2005), Influence of hydroclimatology and socioeconomic conditions on water-related international relations, WATER INTERNATIONAL, 30(3), 270-282.

(TFDD) Transboundary Freshwater Dispute Database. "Product of the Transboundary Freshwater Dispute Database, Department of Geosciences, Oregon State University." Additional information about the TFDD can be found at: http://www.transboundarywaters.orst.edu," accessed 22 November 2012.

Tir, J., and J. T. Ackerman (2009), Politics of Formalized River Cooperation, Journal of Peace Research, 46(5), 623-640.

Toset, H. P. W., N. P. Gleditsch, and H. Hegre (2000), Shared rivers and interstate conflict, Political Geography, 19(8), 971-996.

Turton, A. (2003), A Southern African Perspective on Transboundary Water Management, Environmental Change and Security Program Report, Issue 9, 75-79.

Vörösmarty, C., P. Green, J. Salisbury, and R. Lammers (2000), Global water resources: vulnerability from climate change and population growth, Science, 289(5477), 284-288.

Vörösmarty, C., A. Askew, W. Grabs, R. G. Barry, C. Birkett, P. Döll, B. Goodison, A. Hall, R. Jenne, L. Kitaev, J. Landwehr, M. Keeler, G. Leavesley, J. Schaake, K. Strzepek, S. S. 
Sundarvel, K. Takeuchi, F. Webster, and The Ad Hoc Group (2001), Global water data: A newly endangered species, Eos Trans. $A G U, 82(5), 54-58$.

Wolf, A., K. Stahl, and M. F. Macomber (2003), Conflict and Cooperation within International River Basins: The Importance of Institutional Capacity, Water Resources Update, 125, $31-40$.

Yoffe, S., A. T. Wolf, and M. Giordano (2003), Conflict and Cooperation Over International Freshwater Resources: Indicators of Basins at Risk, Journal of the American Water Resources Association, 39(5), 1109-1126. 
Table 1: Selection of river basins criteria and catchment upstream of gauging station data source.

\begin{tabular}{|l|l|}
\hline Parameter & Data source \\
\hline $\begin{array}{l}\text { No impediments to natural flow } \\
\text { upstream }\end{array}$ & $\begin{array}{l}\text { FAO Africa dams; Meridian Global Dam Database } \\
\text { (2006); and power plants - CARMA } \\
\text { (www.carma.org) }\end{array}$ \\
\hline $\begin{array}{l}\text { Gauging station data: location, } \\
\text { discharge, and year (minimum of 4 in } \\
\text { between 1988-2009) }\end{array}$ & Global Runoff Data Centre \\
\hline $\begin{array}{l}\text { Greater than 30 Km from major water } \\
\text { bodies }\end{array}$ & Global Lakes and Wetlands Database (2004) \\
\hline Sufficient amount of rain for detection & SSM/I \\
\hline International River Basin & $\begin{array}{l}\text { Transboundary Freshwater Dispute Database } \\
\text { (TFDD, 2008) }\end{array}$ \\
\hline $\begin{array}{l}\text { Catchment area upstream of gauging } \\
\text { station is as large as possible to } \\
\text { provide many observations and } \\
\text { degrees of freedom for the model }\end{array}$ & $\begin{array}{l}\text { 15 second accumulation and flow direction grids } \\
\text { (HydroSHEDS, 2006) }\end{array}$ \\
\hline
\end{tabular}

${ }^{a}$ Note: The selection is based on an area greater or equal to $50,000 \mathrm{~km}^{2}$ 
Table 2: Parameters of the BWI and Precipitation models for both basins: Mekong and Zambezi. In parentheses are t-values. ${ }^{* * *}(\mathrm{p}<0.01) ;{ }^{* *}(\mathrm{p}<0.05) ; *(\mathrm{p}<0.10)$.

\begin{tabular}{|c|c|c|c|c|}
\hline & \multicolumn{2}{|c|}{ Zambezi } & \multicolumn{2}{|c|}{ Mekong } \\
\hline & BWI model & $\begin{array}{l}\text { Precipitation } \\
\text { model }\end{array}$ & BWI model & $\begin{array}{c}\text { Precipitation } \\
\text { model }\end{array}$ \\
\hline Dependent Variable & $Q_{m(B W I)}$ & $Q_{m(\text { precip })}$ & $Q_{m(B W I)}$ & $Q_{m(\text { precip })}$ \\
\hline Intercept & $\begin{array}{l}879.74 \\
(160.82) * * *\end{array}$ & $\begin{array}{l}199.78 \\
(112.90) *\end{array}$ & $\begin{array}{l}750.647 \\
(900.148)\end{array}$ & $\begin{array}{l}720.17 \\
(235.94) * *\end{array}$ \\
\hline Linear term & $\begin{array}{l}-1736.24 \\
(245.87) * * *\end{array}$ & $\begin{array}{l}6.19 \\
(2.83) * *\end{array}$ & $\begin{array}{l}-773.145 \\
(1318.125)\end{array}$ & $\begin{array}{l}11.86 \\
(7.23)\end{array}$ \\
\hline Quadratic term & $\begin{array}{l}1150.84 \\
(84.47) * * *\end{array}$ & $\begin{array}{l}0.0196 \\
(0.0134)\end{array}$ & $\begin{array}{l}1236.598 \\
(445.610) * *\end{array}$ & $\begin{array}{l}0.0972 \\
(0.0424) * *\end{array}$ \\
\hline Lag time (months) & 2 & 2 & 2 & 2 \\
\hline Observations & 198 & 194 & 44 & 44 \\
\hline $\mathrm{DF}$ & 195 & 191 & 41 & 41 \\
\hline RMSE & 453.00 & 820.9 & 647.5 & 561.8 \\
\hline $\mathrm{R}^{2}$ & 0.832 & 0.456 & 0.831 & 0.873 \\
\hline F-test & $\begin{array}{l}483.4 * * * \\
(2 \text { and } 195 \mathrm{DF})\end{array}$ & $\begin{array}{l}80.07 * * * \\
(2 \text { and } 191 \mathrm{DF})\end{array}$ & $\begin{array}{l}101.1 * * * \\
(2 \text { and } 41 \mathrm{DF})\end{array}$ & $\begin{array}{l}141 * * * \\
(1 \text { and } 41 \mathrm{DF})\end{array}$ \\
\hline $\begin{array}{l}\text { Stud. Breusch- } \\
\text { Pagan }\end{array}$ & $\begin{array}{l}38.43 * * * \\
\text { (on } 2 \mathrm{DF} \text { ) }\end{array}$ & $\begin{array}{l}51.19 * * * \\
\text { (on } 2 \mathrm{DF} \text { ) }\end{array}$ & $\begin{array}{l}6.32 * * \\
\text { (on } 2 \mathrm{DF} \text { ) }\end{array}$ & $\begin{array}{l}13.31 * * * \\
\text { (on } 2 \mathrm{DF} \text { ) }\end{array}$ \\
\hline
\end{tabular}


Table 3: Flow Data in the UMB and LMB as Calculated by the BWI

\begin{tabular}{|l|l|l|l|l|}
\hline Description & $\mathrm{km}^{3} /$ year & $\mathrm{m}^{3} / \mathrm{sec}$ & $\begin{array}{l}\text { Cumulative } \\
\text { Probability }\end{array}$ & Probability \\
\hline \multicolumn{5}{|c|}{ a. Flow at Chiang Saen (UMB coming from China) } \\
\hline a1: Mean - 1 SD & 27.863 & 882 & 0.117 & 0.117 \\
\hline a2: Mean & 76.271 & 2,416 & 0.588 & 0.471 \\
\hline a3: Mean +1 SD & 124.679 & 3,950 & 0.862 & 0.274 \\
\hline a4: Mean + 2 SDs & 173.087 & 5,484 & 0.961 & 0.099 \\
\hline \multicolumn{5}{|c|}{ b. Flow of LMB Tributaries } \\
\hline b1: Mean - 1 SD & 345.536 & 10,949 & 0.414 & 0.414 \\
\hline b2: Mean & 429.623 & 13,614 & 0.576 & 0.162 \\
\hline b3: Mean + 1 SD & 513.710 & 16,278 & 0.710 & 0.134 \\
\hline b4: Mean + 2 SD & 597.797 & 18,943 & 0.809 & 0.099 \\
\hline
\end{tabular}

Table 4: Water Balances $\left(\mathrm{km}^{3} /\right.$ year) for mean flows at UMB and LMB tributaries

\begin{tabular}{|c|c|c|c|c|}
\hline Variable & $\begin{array}{c}\text { UMB } \\
\text { Wet } \\
\text { Season }\end{array}$ & $\begin{array}{c}\text { UMB } \\
\text { Dry } \\
\text { Season }\end{array}$ & $\begin{array}{c}\text { LMB } \\
\text { Wet } \\
\text { Season }\end{array}$ & $\begin{array}{l}\text { LMB Dry } \\
\text { Season }\end{array}$ \\
\hline Inflow water & 66.737 & 9.534 & 375.920 & 53.703 \\
\hline River flow from upstream & & & 60.522 & 7.151 \\
\hline Water availability & 66.737 & 9.534 & 436.442 & 60.854 \\
\hline Stored water total ${ }^{\mathrm{a}}$ & 5.474 & & 12.888 & \\
\hline H\&I water use & 0.741 & 0.529 & 1.895 & 1.352 \\
\hline Outflow water from dams & 60.522 & 13.565 & 421.659 & 69.735 \\
\hline Irrigation & & 6.414 & & 6.579 \\
\hline River flow to Tonle Sap & & & 86.950 & -86.950 \\
\hline River flow to down/estuaries & 60.522 & 7.151 & 334.709 & 150.107 \\
\hline Hydropower water total ${ }^{b}$ & 69.226 & 74.912 & 60.003 & 42.860 \\
\hline
\end{tabular}

Notes: ${ }^{\mathrm{a}} W$ ater is stored on main river in UMB and on tributaries in LMB.

${ }^{\mathrm{b}}$ Hydropower is produced on main river in UMB and on tributaries in LMB. 
Table 5: Economic Performance of UMB and LMB for Mean Flow (Billion USD/Year)

\begin{tabular}{|l|c|c|}
\hline & $\begin{array}{l}\text { UMB } \\
\text { Wet+Dry } \\
\text { Seasons }\end{array}$ & $\begin{array}{l}\text { LMB } \\
\text { Wet+Dry } \\
\text { Seasons }\end{array}$ \\
\hline Net Welfare & 2.656 & 6.663 \\
\hline Aggregated Economic Value & 2.656 & 6.663 \\
\hline Econ Value Households \& Industry & 0.408 & 1.957 \\
\hline Econ Value Fishery & 0.241 & 2.728 \\
\hline Econ Value Irrigation & 1.193 & 1.772 \\
\hline Econ Value Hydro Main & 0.815 & \\
\hline Econ Value Hydro Tributaries & & 0.206 \\
\hline Aggregated Economic Costs & & 0.000 \\
\hline Costs Saltwater Intrusion & & 0.000 \\
\hline
\end{tabular}

Table 6: Estimated Poisson relationship between BAR scores and level of flow variability

\begin{tabular}{|l|l|l|}
\hline \multirow{2}{*}{ Independent Variable } & \multicolumn{1}{|c|}{ Equation with no basin dummy } & \multicolumn{1}{|c|}{ Equation with basin dummy } \\
\cline { 2 - 3 } & \multicolumn{1}{|c|}{ BAR Score } \\
\hline Flow variability & -0.000765 & -0.0008455 \\
& $(-2.43)^{* * *}$ & $(-2.45)^{* * *}$ \\
\hline Basin Dummy & & .262296 \\
(Zambezi=1; Mekong=0) & & $(0.82)$ \\
\hline Intercept & 0.759385 & 0.564156 \\
& $(4.91)^{* * *}$ & $(1.93)^{* *}$ \\
\hline Pseudo R-Square & 0.0927 & 0.1007 \\
\hline Log Likelihood & -39.286 & -38.941 \\
\hline LR Chi Square & $8.03^{* * *}$ & $8.72^{* * *}$ \\
\hline Observations & 22 & 22 \\
\hline
\end{tabular}

$* *$ indicates a coefficient significant at $5 \% ; * * *$ indicates a coefficient significant at $1 \%$ or less 


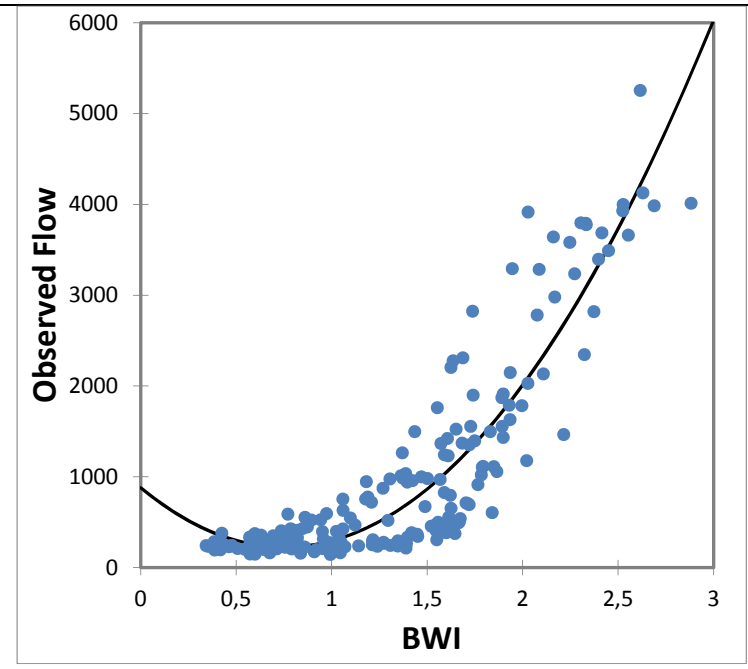

Figure 1.1: Average of all flow $\left(\mathrm{m}^{3} / \mathrm{s}\right.$ per month. $\mathrm{y}-$ axis) and wetness index (index. $x$-axis) in sample catchment area of the Zambezi river basin in a nonlinear regression.

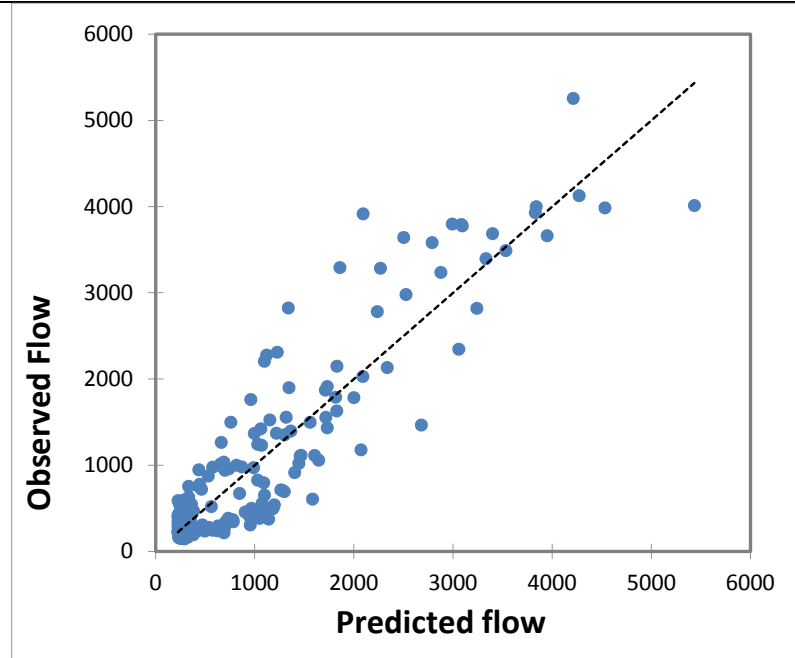

Figure 1.2: Predicted $\left(\mathrm{m}^{3} / \mathrm{s}\right.$ per month. $\mathrm{x}$-axis) versus calculated average flow $\left(\mathrm{m}^{3} / \mathrm{s}\right.$ per month. y-axis) in sample catchment area of the Zambezi river basin from BWI model.

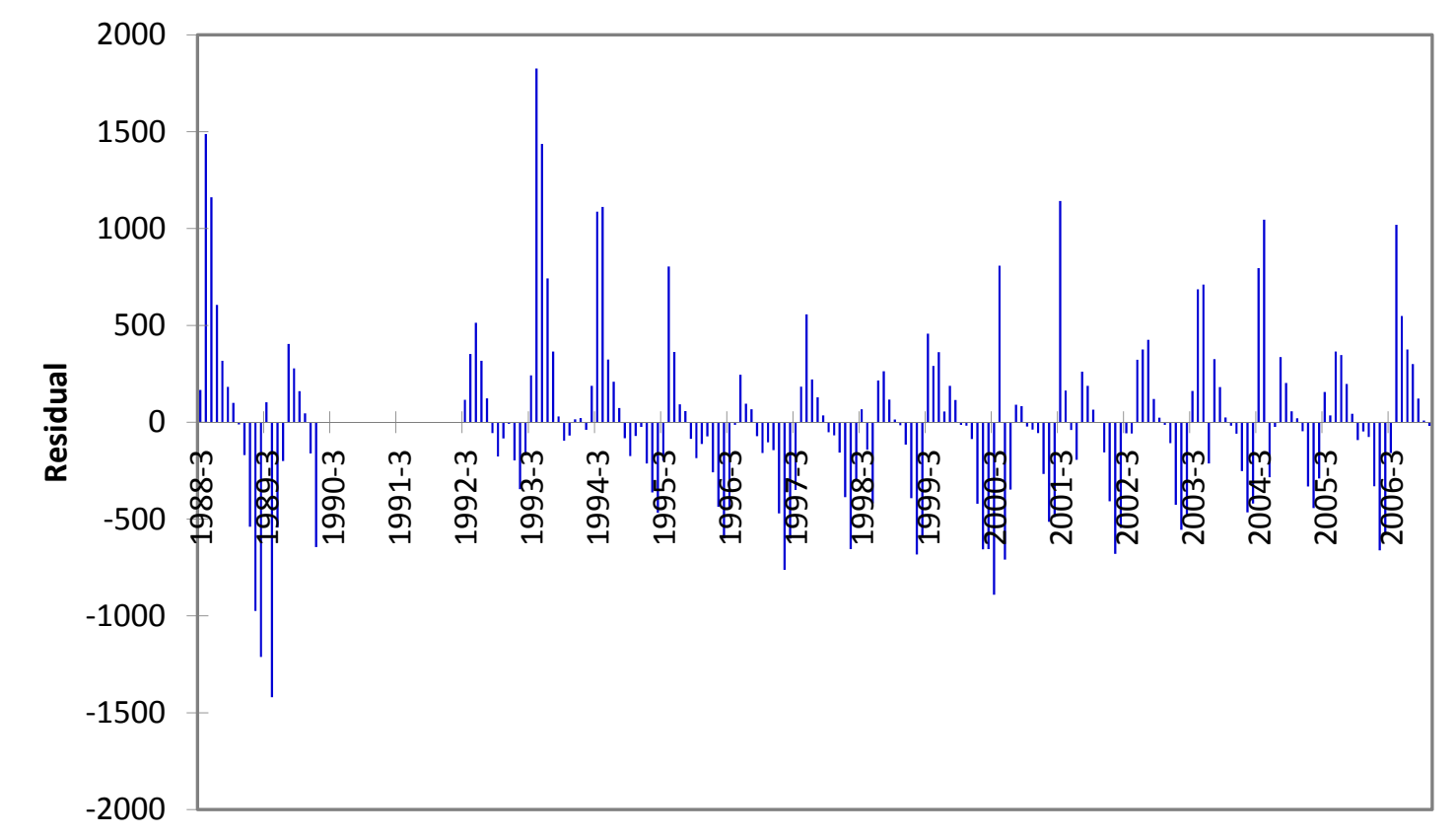

Figure 1.3: Observations in years (x-axis) and the residuals $\left(\mathrm{m}^{3} / \mathrm{s}\right.$ per month. $y$-axis) of the Zambezi river basin BWI model. SSM/I data are not available from mid-1990 through 1991. Thus no residuals are in the figure for that time period and the two month lag. 


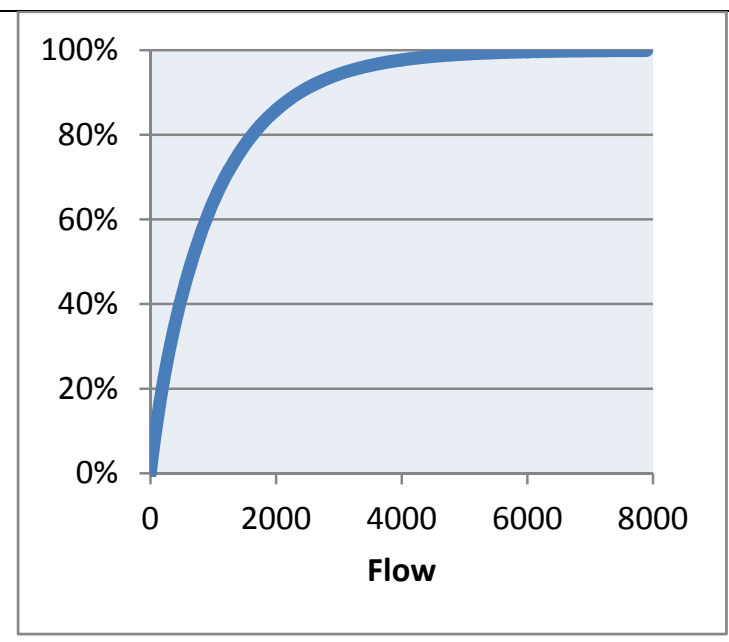

Figure 1.4: Cumulative Distribution of Flow using a gamma distribution (percent. y-axis) and flow $\left(\mathrm{m}^{3} / \mathrm{s}\right.$ per month. $\mathrm{X}$-axis) of the Zambezi river basin sample area

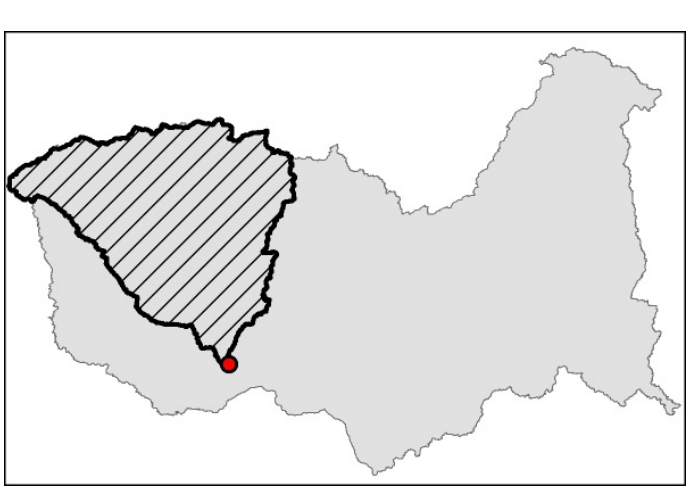

Figure 1.5: Map of Zambezi basin (grey) with the selected gauge data (point). international border (line). and respective catchment (hatched)

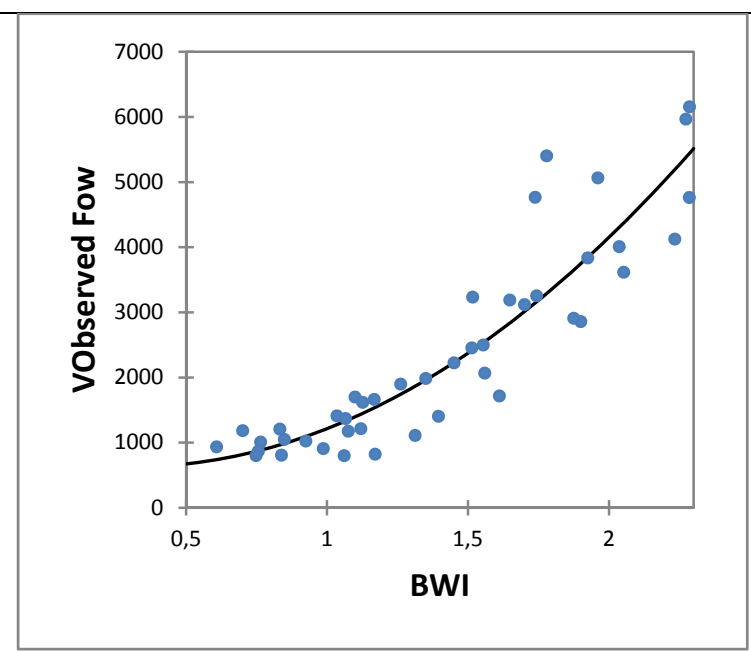

Figure 2.1: Average of all flow $\left(\mathrm{m}^{3} / \mathrm{s}\right.$ per month. $\mathrm{y}$ axis) and wetness index (index. $x$-axis) in sample catchment area of the Mekong river basin in a nonlinear regression.

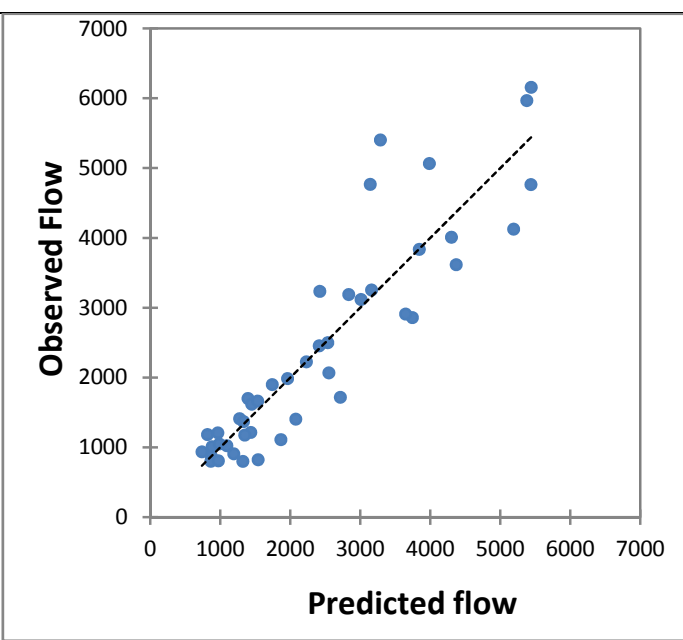

Figure 2.2: Predicted $\left(\mathrm{m}^{3} / \mathrm{s}\right.$ per month. $\mathrm{x}$-axis) versus calculated average flow $\left(\mathrm{m}^{3} / \mathrm{s}\right.$ per month. $\mathrm{y}$-axis) in sample catchment area of the Mekong river basin from BWI model. 


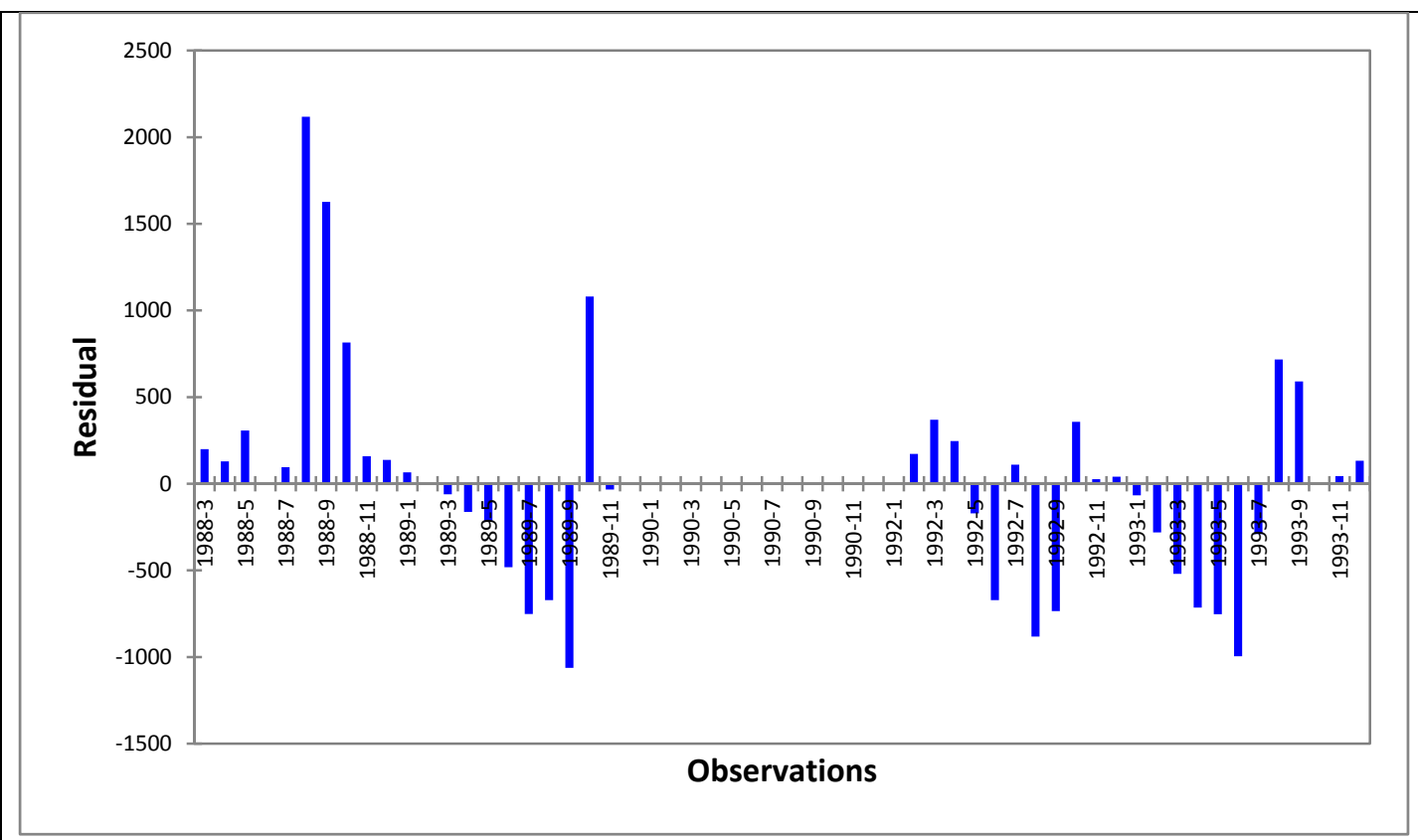

Figure 2.3: Observations in years $\left(\mathrm{m}^{3} / \mathrm{s}\right.$ per month. $\mathrm{x}$-axis) and the residuals $\left(\mathrm{m}^{3} / \mathrm{s}\right.$ per month. $y$-axis $)$ of the Mekong BWI river basin model.

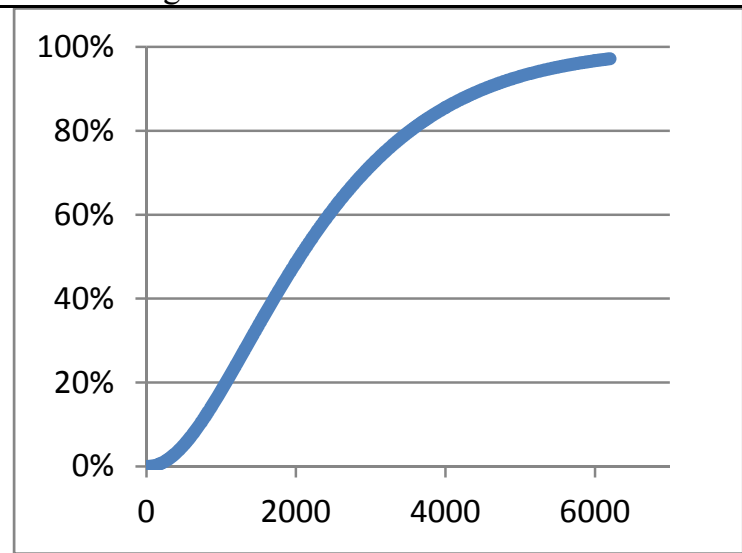

Figure 2.4: Cumulative Distribution of Flow using a gamma distribution (percent. y-axis) and flow $\left(\mathrm{m}^{3} / \mathrm{s}\right.$ per month. $\mathrm{x}$-axis) of the Mekong river basin sample area

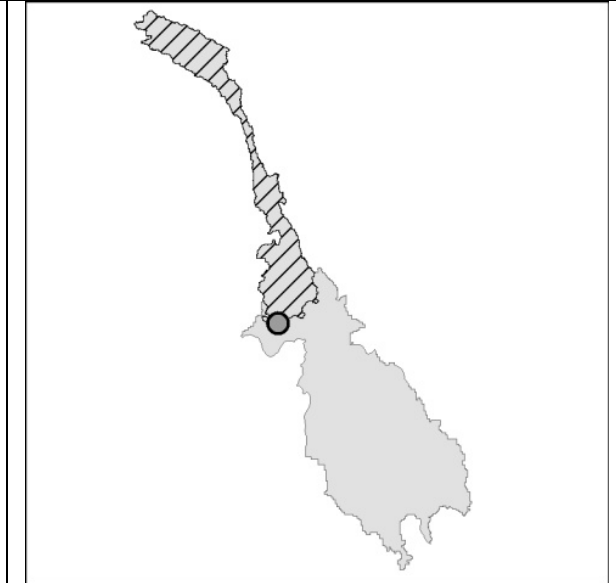

Figure 2.5: Map of Mekong basin (grey) with the selected gauge data (point) and respective catchment (hatched). 


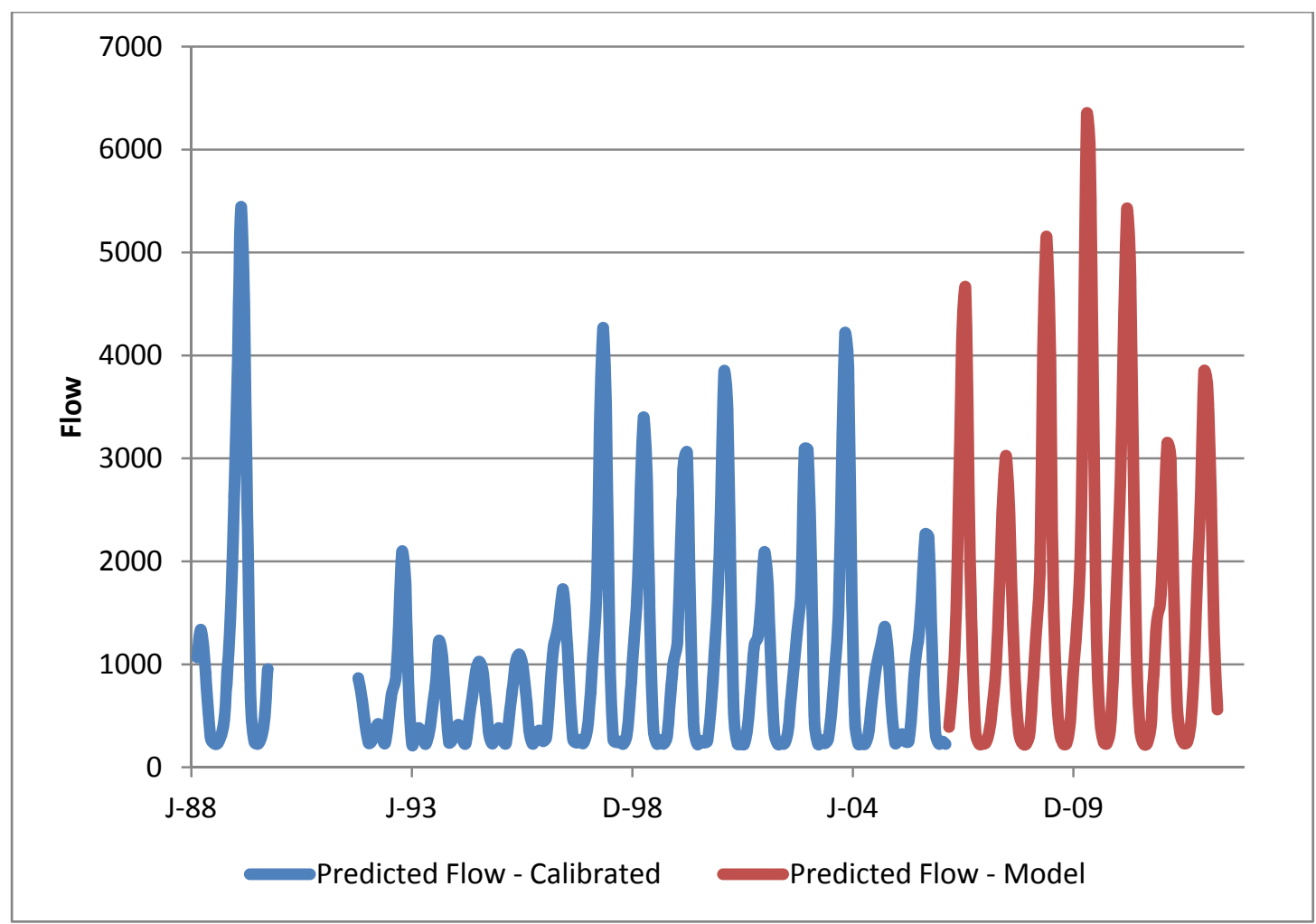

Figure 3 : The Zambezi values of runoff ( $\mathrm{m}^{3} / \mathrm{s}$ per month, y-axis) and time (month / years--, January 1988 through June 2012) display seasonality with both the predicted flow from the period of record (with observed gauging station data) (blue) and the predicted values from the Zambezi runoff BWI model after the period of record (red) (see Equation 4). Missing values are due to the lack of reliable SSM/I data. 


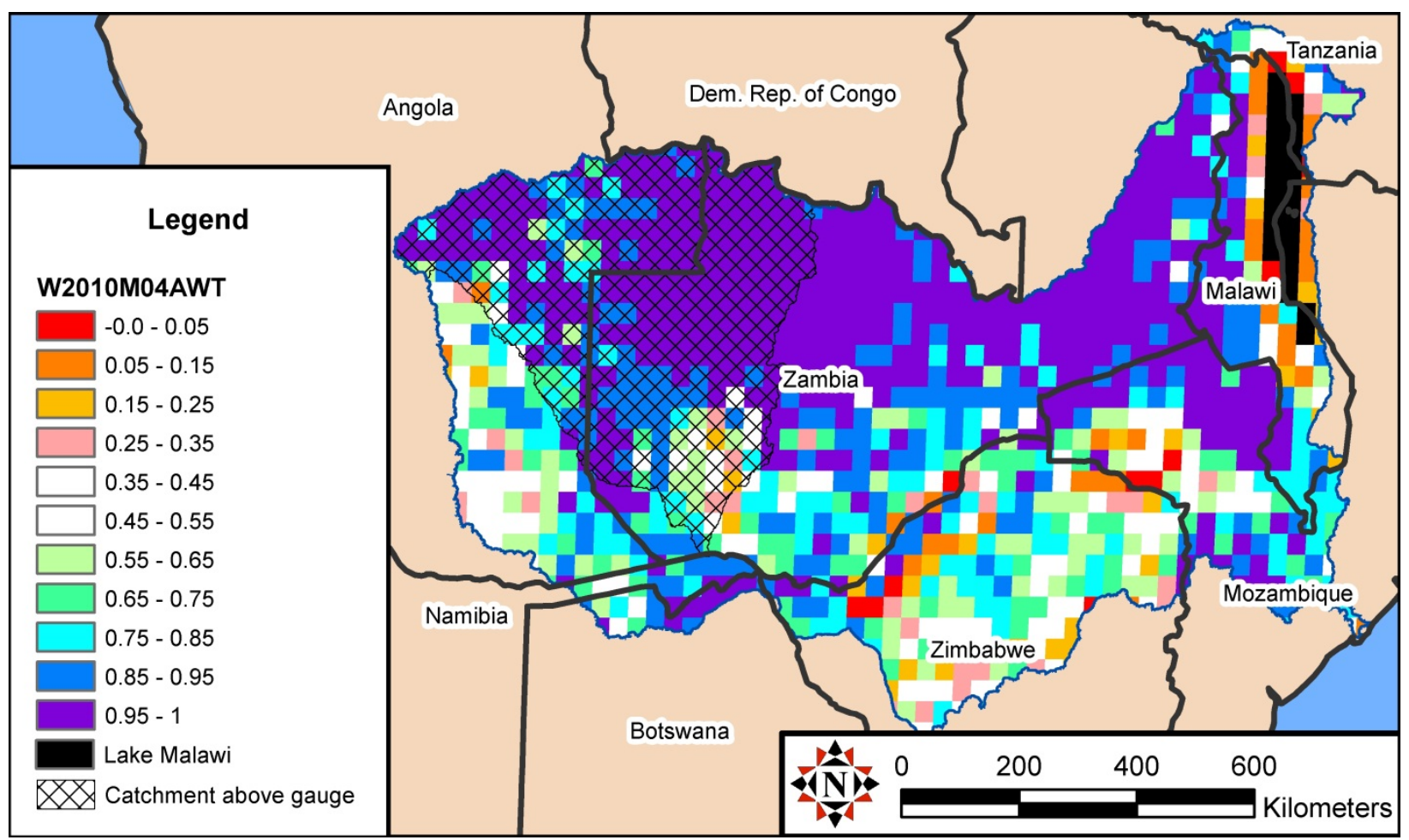

Figure 4: Surface Wetness Values for a section of the Zambezi River: April 2010, where .00--.05 (red) means that less than 5\% of the time is it this dry, 45-.55 (white) is the expected normal soil moisture, and .95-1.0 (purple) means less than 5\% of the time is it this wet 


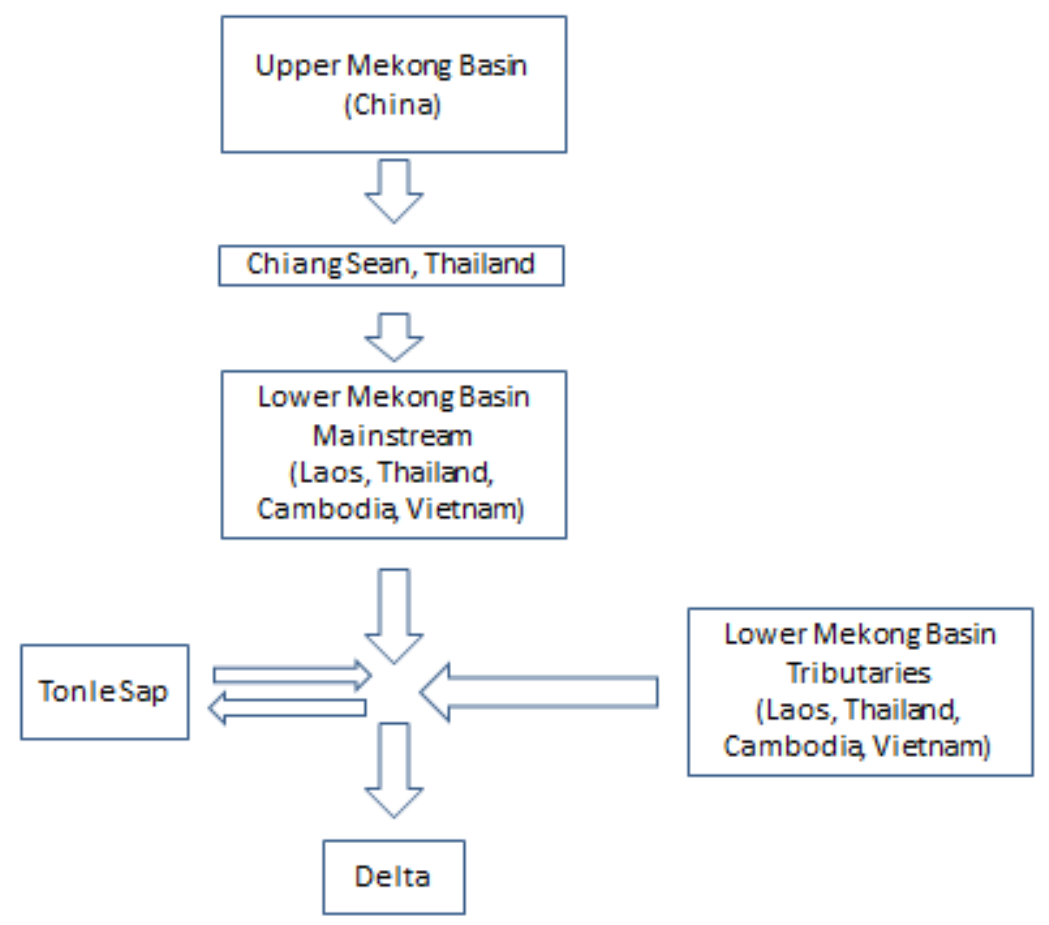

Figure 5: Simple Representation of the Mekong River Basin Used in Our Model (Modified from Houba et al., 2013).

Note: We exclude Burma from the analysis because of it's negligible share of water and land in the basin

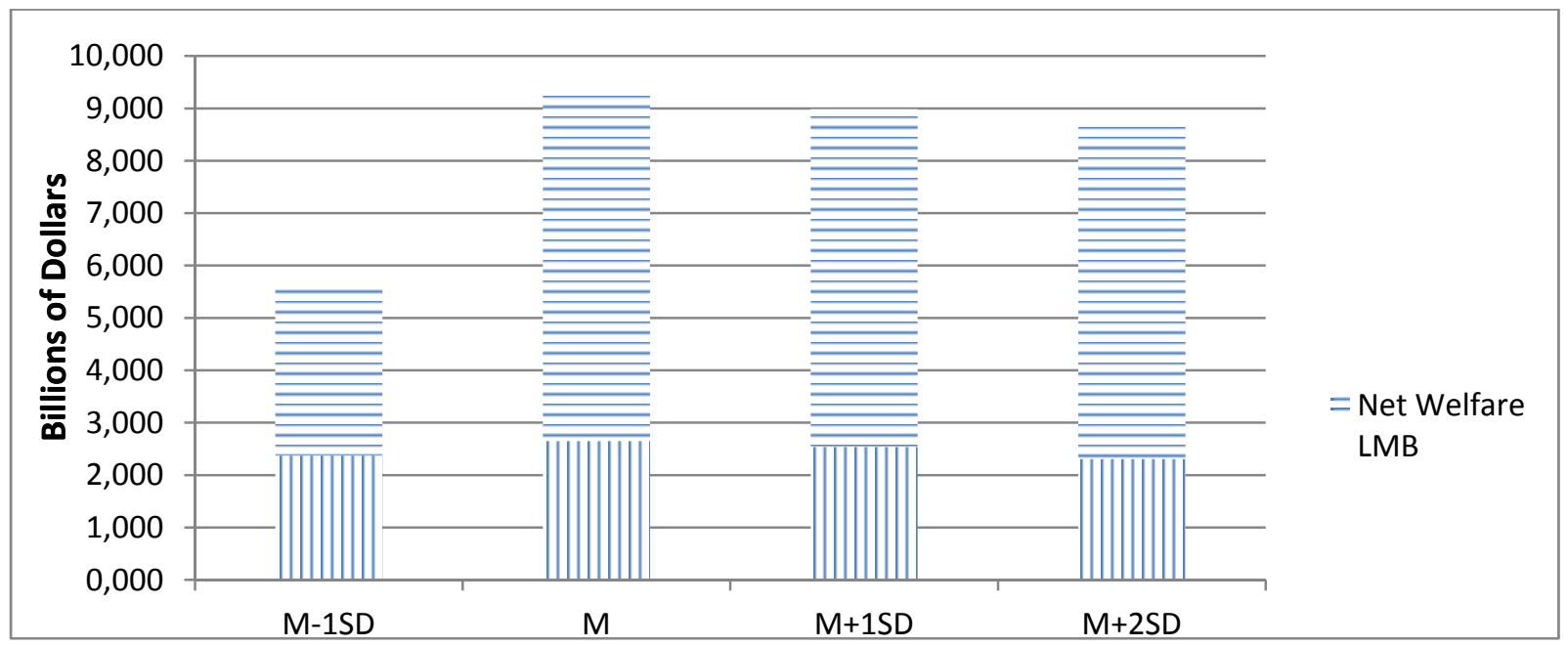

Figure 6: Net Benefits in the Mekong Basin as a Function of Flow Distribution (M=Mean; $\mathrm{SD}=$ Standard Deviation) 


\section{Auxiliary material for}

\section{Assessing the Economic and Political Impacts of Climate Change on International River Basins using Surface Wetness in the Zambezi and Mekong Basins}

Brian Blankespoor ${ }^{1}$, Alan Basist $^{2}$, Ariel Dinar ${ }^{3}$, Shlomi Dinar $^{4}$, Harold Houba $^{5}$, Neil Thomas ${ }^{6}$

${ }^{1}$ Development Research Group, World Bank, Washington DC, USA

${ }^{2}$ Weather Predict Consulting, Ashville, North Carolina, USA

${ }^{3}$ University of California, Riverside, California, USA

${ }^{4}$ Florida International University, Miami, Florida, USA

${ }^{5}$ VU University Amsterdam, and Tinbergen Institute, Amsterdam, The Netherlands

${ }^{6}$ Resource Data Incorporated, Asheville, North Carolina, USA

Water Resources Research 


\section{ANNEX: BACKGROUND DATA AND RESULTS OF FLOW AND ECONOMIC}

\section{ESTIMATES}

Table A1: Selected river basins have a range of physical and socio-economic characteristics

\begin{tabular}{|l|l|l|}
\hline & Mekong & Zambezi \\
\hline Length $(\mathrm{km})$ & 4,350 & 2,574 \\
\hline Area $\left(\mathrm{km}^{2}\right)$ & 787,836 & $1,390,000$ \\
\hline Population density $/ \mathrm{km}^{2}$ & 71 & 21 \\
\hline Population & $55,800,000$ & $28,800,000$ \\
\hline Treaty with water quantity & Yes & Yes \\
\hline River basin organization & $\begin{array}{l}\text { Mekong River } \\
\text { Comission }\end{array}$ & Zambezi River Authority \\
\hline Riparians & $\begin{array}{l}\text { China, Burma, } \\
\text { Thailand, Laos, } \\
\text { Cambodia, and } \\
\text { Vietnam }\end{array}$ & $\begin{array}{l}\text { Zambia, Angola, Namibia, Botswana, Zambia, } \\
\text { Zimbabwe, and Mozambique, }\end{array}$ \\
\hline Snowmelt & No & No \\
\hline
\end{tabular}

${ }^{a}$ Note: Population statistics based on Landscan 2000 estimates summarized by basin (TFDD, 2008).

Table A2: Geographic results of BWI and Precipitation models for Mekong and Zambezi

\begin{tabular}{|l|l|l|l|l|}
\hline Details & $\begin{array}{l}\text { MEKONG } \\
\text { BWI }\end{array}$ & $\begin{array}{l}\text { MEKONG } \\
\text { PRECIPITATION }\end{array}$ & $\begin{array}{l}\text { ZAMBEZI } \\
\text { BWI }\end{array}$ & $\begin{array}{l}\text { ZAMBEZI } \\
\text { PRECIPITATION }\end{array}$ \\
\hline $\begin{array}{l}\text { Sample area } \\
\left(\mathrm{km}^{2}\right)\end{array}$ & 189,000 & 189,000 & 334,000 & 334,000 \\
\hline $\begin{array}{l}\text { Basin area } \\
\left(\mathrm{km}^{2}\right)\end{array}$ & 787,836 & 787,836 & $1,390,000$ & $1,390,000$ \\
\hline $\begin{array}{l}\text { Sample area of } \\
\text { basin }(\%)\end{array}$ & 24.0 & 24.0 & 24.0 & 24.0 \\
\hline
\end{tabular}

Table A3: Descriptive statistics of variables used in regression

\begin{tabular}{|l|l|l|l|l|l|l|}
\hline Variable & Unit & Mean & Std. Dev. & Min & Max & Obs. \\
\hline MEKONG (1988-1990) at Chiang Saen \\
\hline Precipitation & $\begin{array}{l}\text { mm per } \\
\text { month }\end{array}$ & 74.29 & 59.61 & 3.98 & 202.12 & 23 \\
\hline Wetness value & Index & 1.230 & 0.684 & 0.289 & 2.392 & 23 \\
\hline Lagged runoff & $\begin{array}{l}\mathrm{m}^{3} / \mathrm{s} \text { per } \\
\text { month }\end{array}$ & 2416.93 & 1534.41 & 802.71 & 5404.19 & 23 \\
\hline ZAMBEZI (1988-1990, 1994-2006) at Katima Mulilo & \multicolumn{5}{|l|}{} \\
\hline Precipitation & $\begin{array}{l}\text { mm per } \\
\text { month }\end{array}$ & 83.62 & 72.68 & 0.10 & 268.07 & 173 \\
\hline Wetness value & Index & 1.370 & 0.630 & 0.410 & 2.670 & 173 \\
\hline Lagged runoff & $\begin{array}{l}\text { m } 3 / \mathrm{s} \text { per } \\
\text { month }\end{array}$ & 1003.42 & 1120.09 & 146.53 & 5256.37 & 173 \\
\hline
\end{tabular}


Table A4: Results of Lower Mekong Tributaries Flow Calculations Rainfall and Flow calculations based on BWI in LMB Tributaries.

\begin{tabular}{|c|c|c|}
\hline Year & Rainfall $\left(\mathrm{Km}^{3}\right)$ & Flow $\left(\mathrm{Km}^{3}\right)$ \\
\hline 1979 & 301.084445 & NA \\
\hline 1980 & 392.831077 & NA \\
\hline 1981 & 381.8161629 & NA \\
\hline 1982 & 294.385959 & NA \\
\hline 1983 & 358.2334431 & NA \\
\hline 1984 & 355.3723794 & NA \\
\hline 1985 & 357.9630596 & NA \\
\hline 1986 & 368.0809781 & NA \\
\hline 1987 & 326.9547246 & NA \\
\hline 1988 & 353.0855861 & NA \\
\hline 1989 & 341.5750116 & 515.4447234 \\
\hline 1990 & 372.8781699 & NA \\
\hline 1991 & 328.0012951 & NA \\
\hline 1992 & 310.5509467 & NA \\
\hline 1993 & 301.3852506 & 514.9135076 \\
\hline 1994 & 417.9367671 & 408.539243 \\
\hline 1995 & 365.8844119 & 434.2016602 \\
\hline 1996 & 378.5017076 & 471.8194131 \\
\hline 1997 & 367.9229839 & 467.2052945 \\
\hline 1998 & 331.4261658 & 344.7851164 \\
\hline 1999 & 427.3069798 & 477.8853247 \\
\hline 2000 & 441.9473195 & 654.7337927 \\
\hline 2001 & 412.7670741 & 517.4847902 \\
\hline 2002 & 396.7713065 & 474.3423858 \\
\hline 2003 & 236.7260552 & 412.9405296 \\
\hline 2004 & 350.2866533 & 432.8349133 \\
\hline 2005 & 365.8467925 & 383.1037304 \\
\hline 2006 & 369.7856857 & 422.1853208 \\
\hline 2007 & 382.3513013 & 409.8763471 \\
\hline 2008 & 333.3496104 & 373.2878833 \\
\hline 2009 & 383.4698011 & 351.0495111 \\
\hline 2010 & 349.9857498 & 278.3056003 \\
\hline 2011 & 414.7262144 & 365.7305637 \\
\hline 2012 & 332.2178019 & 311.4288574 \\
\hline MEAN & 358.9237903 & 429.6237385 \\
\hline SD & 42.27545292 & 84.08739645 \\
\hline
\end{tabular}

Source: Authors' calculations 
Table A5: Net Benefit Calculations for various flow values in the Mekong Basin (Billion \$)

\begin{tabular}{|l|l|l|l|l|l|l|l|l|}
\hline & \multicolumn{2}{|l|}{ Mean - 1SD } & \multicolumn{2}{l|}{ Mean } & \multicolumn{2}{l|}{ Mean + 1SD } & \multicolumn{2}{l|}{ Mean + 2 SD } \\
\cline { 2 - 9 } & UMB & LMB & UMB & LMB & UMB & LMB & UMB & LMB \\
\cline { 2 - 9 } & 27.863 & 345.536 & 76.271 & 429.623 & 124.679 & 513.710 & 173.087 & 597.797 \\
\hline Net Welfare Created & 2.376 & 3.222 & 2.656 & 6.663 & 2.544 & 6.445 & 2.313 & 6.336 \\
\hline $\begin{array}{l}\text { Aggregated Economic } \\
\text { Value }\end{array}$ & 2.376 & 6.355 & 2.656 & 6.663 & 2.544 & 6.445 & 2.313 & 6.336 \\
\hline $\begin{array}{l}\text { Econ Value Households \& } \\
\text { Industry }\end{array}$ & 0.408 & 1.957 & 0.408 & 1.957 & 0.408 & 1.957 & 0.408 & 1.957 \\
\hline Econ Value Fishery & 0.128 & 2.772 & 0.241 & 2.728 & 0.167 & 2.077 & 0.082 & 1.109 \\
\hline Econ Value Irrigation & 1.193 & 1.421 & 1.193 & 1.772 & 1.193 & 2.206 & 1.193 & 3.065 \\
\hline Econ Value Hydro Main & 0.647 & & 0.815 & & 0.776 & & 0.629 & \\
\hline $\begin{array}{l}\text { Econ Value Hydro } \\
\text { Tributaries }\end{array}$ & & 0.205 & & 0.206 & & 0.206 & & 0.206 \\
\hline $\begin{array}{l}\text { Aggregated Economic } \\
\text { Costs }\end{array}$ & & 3.133 & & 0.000 & & & & \\
\hline Costs Saltwater Intrusion & & 3.133 & & 0.000 & & & & \\
\hline
\end{tabular}

Source: Authors' calculations. 
Table A6: Flow change from mean and BAR codes.

\begin{tabular}{|r|r|r|r|}
\hline Month/year & $\begin{array}{l}\text { llow (change from mean) } \\
\mathrm{m}^{3} / \mathrm{s} \text { per month }\end{array}$ & $\begin{array}{l}\text { River } \\
\text { basin* }\end{array}$ & \multicolumn{1}{l|}{ BAR } \\
\hline Apr-92 & 50 & 1 & 4 \\
\hline May-92 & 0 & 1 & 4 \\
\hline Jul-92 & -250 & 1 & 1 \\
\hline Aug-95 & -625 & 1 & 6 \\
\hline Apr-97 & -20 & 1 & 4 \\
\hline Aug-97 & -480 & 1 & 4 \\
\hline Jan-98 & 240 & 1 & 0 \\
\hline May-98 & -20 & 1 & 1 \\
\hline Jun-98 & -20 & 1 & 2 \\
\hline Jul-98 & -125 & 1 & 0 \\
\hline Aug-98 & -490 & 1 & 0 \\
\hline Mar-01 & 210 & 1 & 4 \\
\hline Oct-02 & 1125 & 1 & 1 \\
\hline Sep-03 & 1050 & 1 & 1 \\
\hline Jul-04 & -250 & 1 & 4 \\
\hline Aug-88 & 2550 & 0 & 0 \\
\hline Jan-90 & 0 & 0 & 1 \\
\hline Feb-90 & 50 & 0 & 1 \\
\hline Feb-93 & -760 & 0 & 3 \\
\hline Mar-93 & -600 & 0 & 4 \\
\hline Apr-93 & -600 & 0 & 2 \\
\hline Jul-93 & -250 & 0 & 4 \\
\hline Mek019 & & & \\
\hline
\end{tabular}

*Note: $1=$ Zambezi; $0=$ Mekong. 

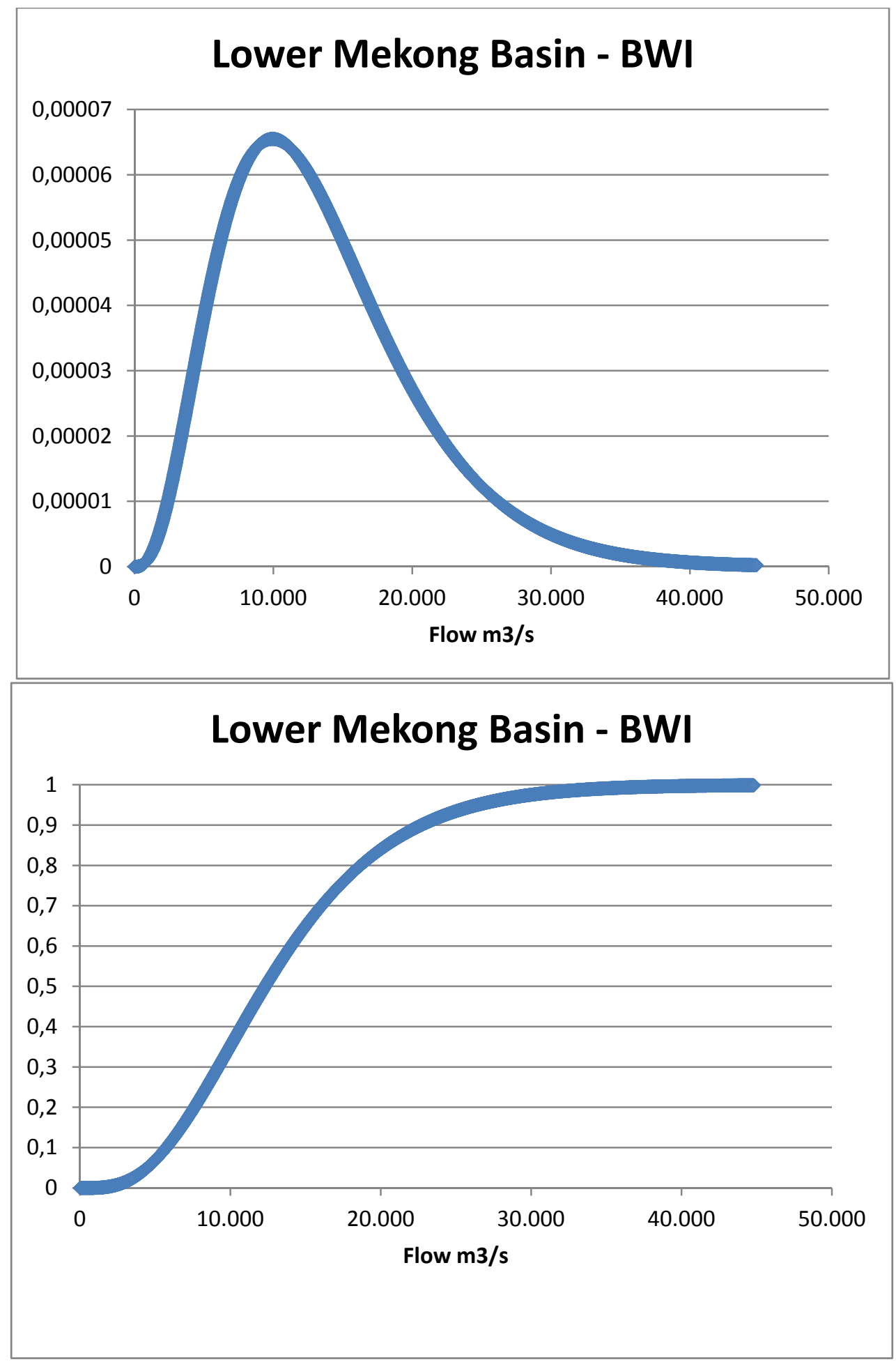

Figure A1: LMB Tributaries Flow Probabilities (cubic meter per second)-The upper panel is the Distribution Function and the lower Panel is the Cumulative Distribution Function. 


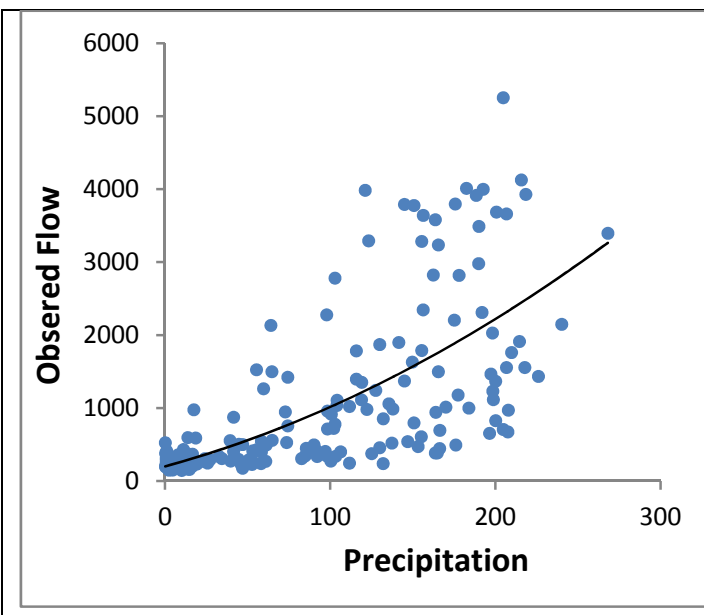

Figure A1.1: Average of estimated flow $\left(\mathrm{m}^{3} / \mathrm{s}\right.$ per month. y-axis) and precipitation (mm per month. $x-$ axis) in sample catchment area of the Zambezi river basin in a nonlinear regression.

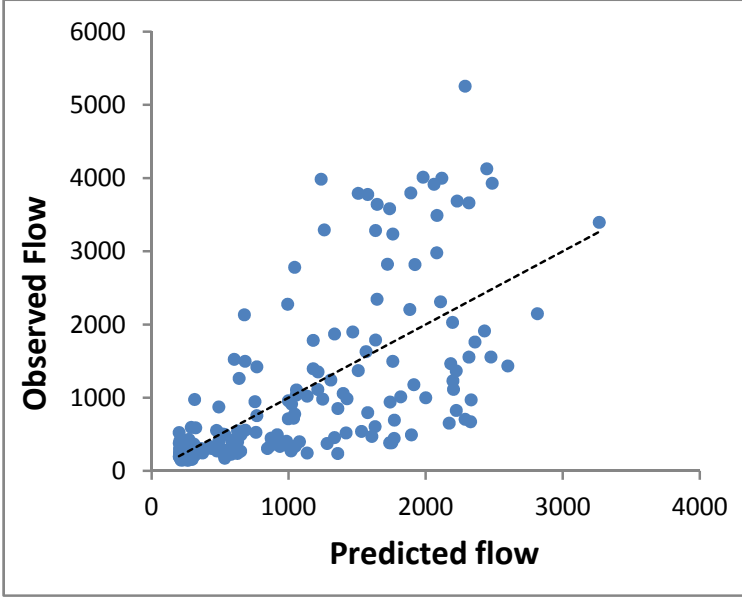

Figure A1.2: Predicted flow ( $\mathrm{m}^{3} / \mathrm{s}$ per month. $\mathrm{x}$-axis) versus calculated average flow $\left(\mathrm{m}^{3} / \mathrm{s}\right.$ per month. $\mathrm{y}$ axis) in sample catchment area of the Zambezi river basin from the precipitation model.

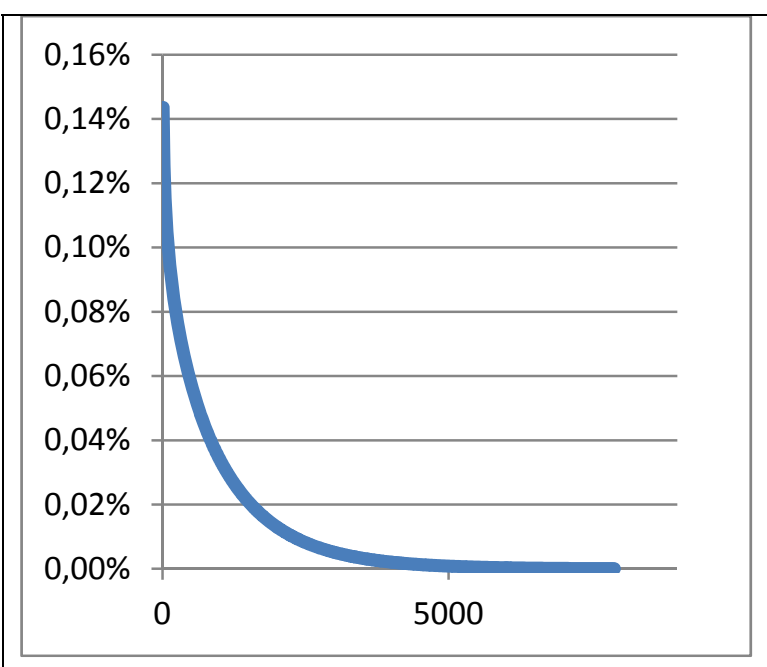

Figure A1.3: Zambezi Probability Distribution of Flow using a gamma distribution (percent. y-axis) and flow $\left(\mathrm{m}^{3} / \mathrm{s}\right.$ per month. $\mathrm{x}$-axis) of the Zambezi river basin sample area.

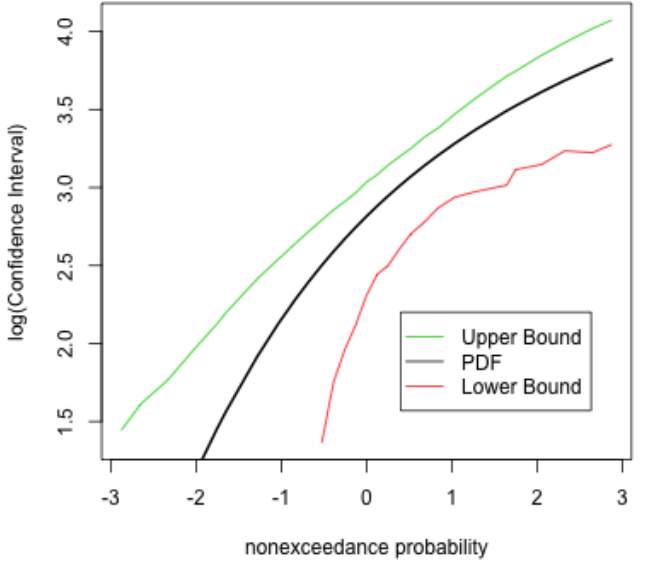

Figure A1.4: Zambezi PDF plot of 90\% confidence intervals generated from a MonteCarlo simulation $(\mathrm{n}=1000)$. $\log 10$ (Confidence interval) on the y-axis and non-exceedance probabilities. Green is the upper bound of the CI and red is the lower bound of the CI. 


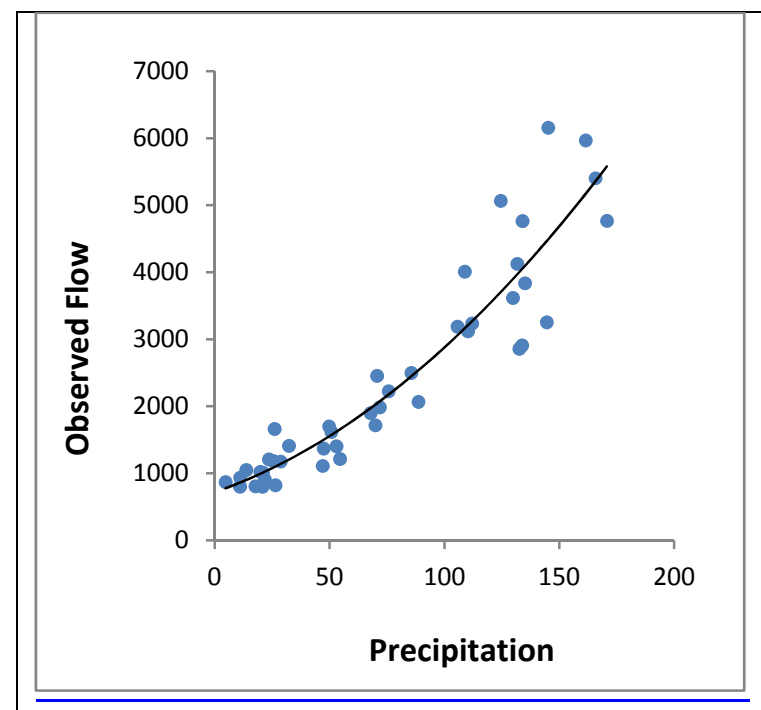

Figure A2.1 : Average of all flow $\left(\mathrm{m}^{3} / \mathrm{s}\right.$ per month. $\mathrm{y}$-axis) and precipitation (mm per month. $\mathrm{x}$-axis) in sample catchment area of the Mekong river basin in a nonlinear regression.

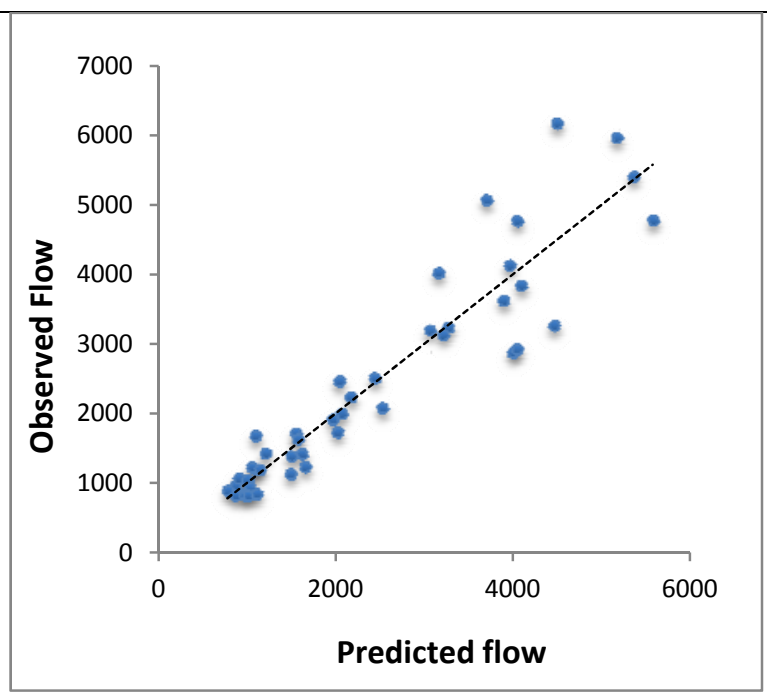

Figure A2.2 : Predicted flow ( $\mathrm{m}^{3} / \mathrm{s}$ per month. $\mathrm{x}$-axis) versus calculated average flow $\left(\mathrm{m}^{3} / \mathrm{s}\right.$ per month. $\mathrm{y}$ axis) in sample catchment area of the Mekong river basin from precipitation model.

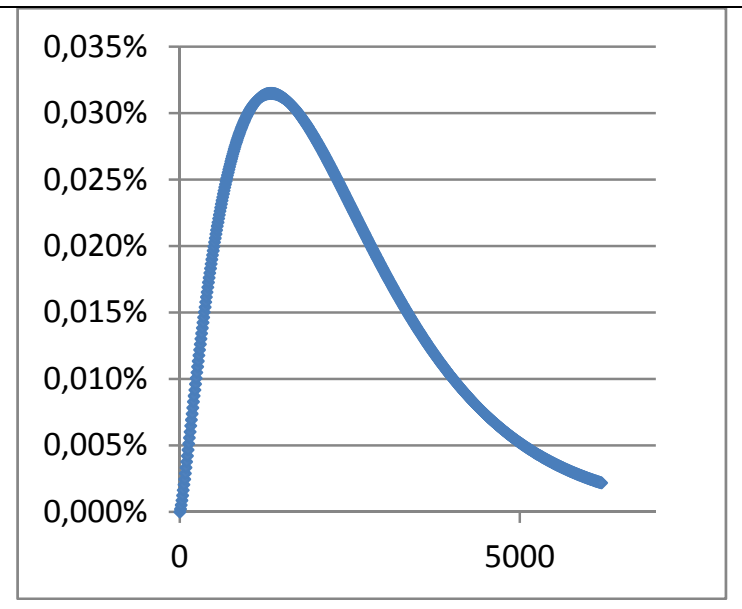

Figure A2.3: Probability Distribution of Flow using a gamma distribution (percent. $y$-axis) and flow $\left(\mathrm{m}^{3} / \mathrm{s}\right.$ per month. $\mathrm{x}$-axis) of the Mekong river basin sample area

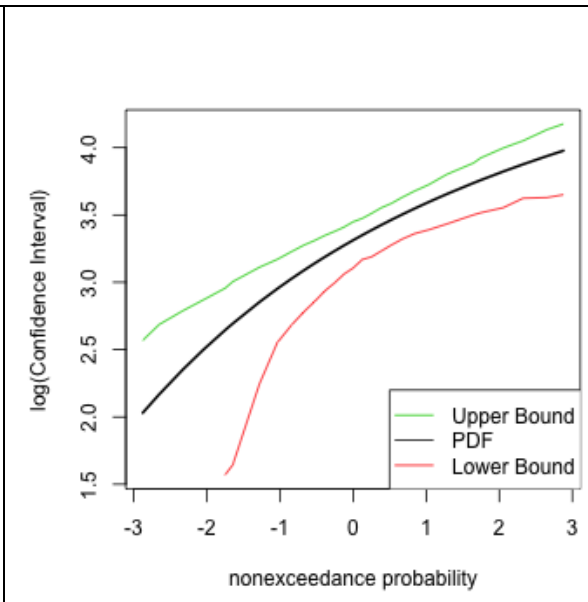

Figure A2.4: Mekong PDF plot of $90 \%$ confidence intervals generated from a MonteCarlo simulation $(\mathrm{n}=1000)$. $\log 10$ (Confidence interval) on the y-axis and non-exceedance probabilities. Green is the upper bound of the CI and red is the lower bound of the CI. 